\title{
Order of Proof: An Accused's Right to Control the Timing and Sequence of Evidence in His Defense
}

\author{
Peter Westen $\dagger$ \\ "The order of witnesses ordinarily must be planned \\ carefully ....."*
}

I have many reasons for paying tribute to David Louisell. Although I was never enrolled in any of his classes, he was in a real sense my teacher, because through his casebooks he structured the way I came to think about both civil procedure and the law of evidence. I remember that as first-year students, my classmates and I considered civil procedure the most challenging of our freshman courses, and Louisell and Hazard ${ }^{1}$ the inost formidable of the casebooks. Yet we also sensed that we were being offered a rare opportunity - that in return for our labor we would be rewarded with a richer vision of the law. We would come to understand, as the authors had, that legal problems are amenable to rational solution, that the law is an appropriate field for philosophical inquiry, and that there is no higher calling for a lawyer than the pursuit of procedural justice. It was probably no accident that procedure becaine my favorite subject in law school and the subject I have since chosen to teach. It is no accident either that my students, in turn, are now learning civil procedure from Louisell and Hazard, and that they, too, consider it to be the most difficult and yet intellectually the most rewarding of their freshman texts.

I have also looked to David Louisell as a standard for iny own professional life. As a student, I admired him for his scholarship and procedural msight. As a graduate, I admired him for his practical skills and for his ability, as a practicing attorney, to combine his scholarship

$\dagger$ Professor of Law, University of Michigan. B.A. 1964, Harvard College; J.D. 1968, Boalt Hall School of Law, University of California, Berkeley.

* 1 D. Louisell \& H. Williams, Medical Malpractice $\$ 11.33$, at 11-98 (1969).

1. D. Louisell \& G. Hazard, Pleading and Procedure (3d ed. 1973). 
with the requirements of appellate advocacy. ${ }^{2}$ And now, as a teacher myself, I admire him for all these things, but perhaps especially for his recognition that law is not value-free, that law presents moral decisions, and that persons who are concerned with a moral life must also be concerned with the substance and procedure of those decisions. ${ }^{3}$

Finally, I miss Louisell's personal warmth. Although our paths failed to cross sometimes for years at a time, he always greeted me with the same rugged cheer and hearty graciousness. I appreciate $\mathrm{m}$ particular soinething he said in a letter during my first year of teaching. I had just completed my first article, a rather longish analysis of the compulsory process clause, and had sent him a copy. He answered, thanking me for the article and bemoaning that his official responsibilities on the National Commission for Biomedical Research left him so little tine for other things. And then, having said so, he took a moment to reflect. In his own words:

I am beginning to become very regretful of so much of life going for things that are not of top priority as far as personal interest is concerned (although arguably they are so from a service viewpoint). For example, I have often regretted that when you last stepped into the office, I did not drop everything and take you for a visit with Albert [Ehrenzweig]. My kids claim I'm too duty oriented. Right now I'd like to drop everything and read Compulsory Process-but I don't.

These few sentences say so many things about Louisell-his sense of duty, his concern for his children, his affection for his friend and col-

2. I had the pleasure of being present on January 13-14, 1969, when Louisell delivered the first of his two oral arguments to the U.S. Supreme Court for the appellants in Gunn v. University Comm., 399 U.S. 383 (1970). In addition to Gunn, Louisell also presented oral arguments in United States v. Johnson, 383 U.S. 169 (1966), McGrath v. Kristensen, 340 U.S. 162 (1950), and DeMeerleer v. Michigan, 329 U.S. 663 (1947), and, only before the U.S. Supreme Court, appeared as counsel in Kirk v. Board of Regents, 396 U.S. 554 (1970), Arens v. Village of Rogers, 347 U.S. 949 (1954), Pearson v. Gariepy, 346 U.S. 909 (1953), Dart Transit Co. v. ICC, 345 U.S. 980 (1953), Risberg v. Duluth, Missabe \& Iron Range Ry., 342 U.S. 832 (1951), Morehouse v. Michigan, 341 U.S. 922 (1951), Crane v. Michigan, 338 U.S. 848 (1949), DeMeerleer v. Michigan, 336 U.S. 946 (1949), Lobaido v. Michigan, 335 U.S. 829 (1948), Cole v. New Jersey, 334 U.S. 851 (1948), In re Gordon, 334 U.S. 811 (1948), and Gordon v. Scudder, 332 U.S. 830 (1947).

It is not fortuitous that Louisell succeeded in combining his scholarship with the skills of practical advocacy, because he made no secret of his admiration for those who were able to combine "the disciplined thought habits of the systematic theorist" with "the practicing lawyer's mastery of litigation as an art." Louisell, The Theory of Criminal Discovery and the Practice of Criminal Law, 14 VAND. L. Rev, 921 (1961) (in honor of Professor Edmund Morgan).

3. This is best illustrated by Louisell's passionate involvement in the controversial issues of abortion and of state aid to parochial sclools-issues on which he stood in fundamental disagreement with the U.S. Supreme Court on the appropriate balance of values. See Louisell \& Noonan, Constitutional Balance, in THE MORALITY OF ABortion, 220, 230, 245, 253-54 (1970); Louisell, Does the Constitution Require a Purely Secular Society?, 26 CATH. U.L. REv. 20, 22 (1976); Louisell, Book Review, 83 YALE L.J. 197 (1973); Louisell, Abortion, the Practice of Medicine and the Due Process of Law, 16 U.C.L.A. L. REv. 233 (1969); Louisell, The Man and the Mountain: Douglas on Religious Freedom, 73 YALE L.J. 975 (1964); Jackson \& Louisell, Religion, Theology, and Public Higher Education, 50 CALIF. L. REv. 751 (1962). 
laborator, Albert Ehrenzweig, his thoughtfulness in remeinbering that I, too, loved and admired Ehrenzweig. But what touched me the most was what he said at the end: his graciousness in saying that he felt tempted to drop everything and read my article, combimed with his candor in admitting that he would ultimately resist the temptation.

I have chosen as the text for iny remarks the Supreme Court's decision in Brooks $v$. Tennessee. ${ }^{4} \mathrm{I}$ have no idea what Louisell himself thought of Brooks. As far as I can tell, he never discussed the case in print. Yet Brooks involves many of the principal themes of his life's work-the privilege agaimst self-incrimination, the right to the assistance of counsel, and the right of a defendant to testify on his own behalf. The Court's opinion would also have interested Louisell, because examination reveals the case to be something quite different from what it purports to be. If my analysis is correct, the decision cannot rationally be explamed on any of the three grounds just mentioned. Rather, if the case was correctly decided, it is because of a different and altogether novel principle of procedural fairness-that a defendant in a criminal case has a constitutional interest in being able to control the timing and sequence of evidence in his defense.

\section{I}

\section{The CourT's Decision}

The facts in Brooks are sinple. The defendant Brooks was indicted on the charges of arined robbery and unlawful possession of a pistol. At the close of the state's case, Brooks, through his counsel and with the prosecutor's consent, moved to postpone his own testimony until after other witnesses had testified for the defense. The trial court denied the notion, stating that "the law is, as you know it to be, that if a defendant testifies, he has to testify first." 5 The trial court based its ruling on a Tennessee statute requiring a criminal defendant to testify, if at all, as the first witness for the defense: "In the trial of all . . . criminal proceedings, the party defendant thereto may, at his own request . . . be a competent witness to testify therein . . . . But the defendant desiring to testify shall do so before any other testimony for the defense is heard by the court trying the case." ${ }^{6}$ Brooks proceeded

4. 406 U.S. 605 (1972). The opinion of the Court was written by Justice Brennan. Justice Stewart concurred in the judgment and joined that part of the Court's opinion based on the right to counsel. Chief Justice Burger and Justice Rehnquist each wrote separate dissenting opinions which the other of them and Justice Blackmun both joined. Brooks went almost unnoticed by the scholarly community, with the exception of Professor Amsterdam, who said at the time that Brooks was a "dark horse" whose "implications . . . [were] staggering." Amsterdain, A Selective Survey of Supreme Court Decisions in Criminal Law and Procedure, 9 CRIM. L. Bull. 389, 404 (1973).

5. 406 U.S. at 606.

6. TenN. Code ANN. $\$ \$ 40-2402$ to 40-2403 (1975 Replacement). 
with his case-in-chief by calling two other witnesses to testify on his behalf, but did not take the witness stand himself. He was thereafter convicted and his conviction was affirmed on appeal.

The Supreme Court, dividimg six to three, reversed the conviction. The Court recognized that the Tennessee statute served a legitimate purpose. The statute was designed to strike a balance between the state's interest in preventing witnesses from falsely tailoring their testi1nony to conform to the testimony of prior witnesses and the defendant's constitutional imterest in being present in the courtroom "at every stage"7 of his trial. With respect to ordinary witnesses, the solution was simple: the state sequestered the witnesses to prevent their overhearing the testimony of other witnesses until they were called to testify. That solution, however, could not be applied to the defendant because of his riglit to remain in the courtroom at all times. Yet if a defendant were allowed to overhear what his witnesses had to say before taking the witness stand, he could "adjust his testnnony to what his witnesses . . . had to say on the matter." 8 Accordingly, the state fashioned a compromise solution. It permitted defendants to remam in the courtroom, but required those desiring to testify on their own behalf to take the witness stand before any other witnesses for the defense. Justice Rehnquist put the statute in a nutshell:

The Tennessee statute in question is, as the Court notes in its opinion, based upon an accommodation between the traditional policy of sequestering prospective witnesses before they testify and the right of the criminal defendant to be present during his trial. Since the defendant may not be sequestered against his will while other witnesses are testifying, the State has placed a nore limited restriction on the presentation of his testimony. The defendant is required to testify, if he chooses to do so, as the first witness for the defense. ${ }^{9}$

Nonetheless, while recognizmg that the Tennessee statute "does reflect a state interest in preventing testimonial influence," 10 the Court held that the state's interest was "not . . . sufficient"11 to justify its effect on two constitutional interests of the defendant. First, the statute imposed "an mipermissible restriction on the defendant's right against self-incrimination," 12 by inposing a "penalty"13 on the defendant for refusing to take the witness stand by thereafter "keeping him off the stand entirely . ..."14 Second, the statute violated the defendant's

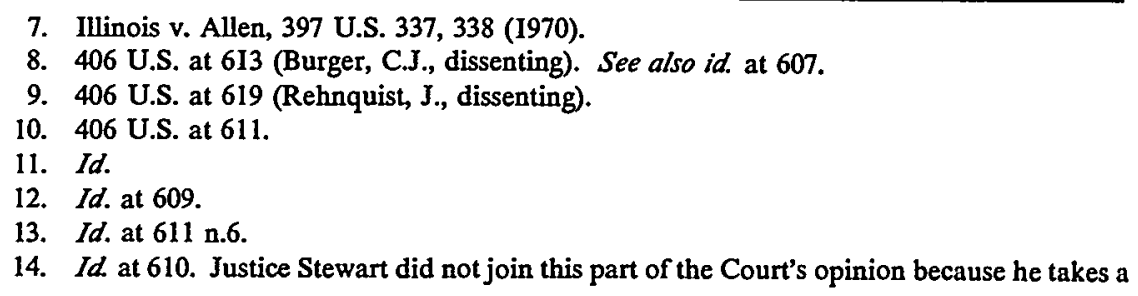


constitutional right to "the guiding hand of counsel" 15 by prohibiting the defendant from acting on the "professional judgment"16 of his lawyer in deciding "when in the course of presenting his defense . . . [to] take the stand."17

II

\section{The Privilege Against Self-Incrimination}

Louisell himself was fascinated by the privilege against self-incrimination. He referred to the privilege, almost with affection, as a "good" 18 and "valued friend" 19 and as a "cornerstone of our accusatorial system." 20 But it is not at all clear that Louisell would have agreed with the Court's reasoning in Brooks. Despite his interest in the privilege, he was "uncertain"21 about the "true justification" for the privilege. As he put it, "I have remained inore uncertain about [the privilege's] contemporary value than about any other problem in evidence or constitutional law . ..."22 Indeed, in his last and most thoughtful article on the privilege, he studiously avoided taking a position on whether the state could constitutionally compel a defendant to disclose his trial defenses in advance of trial..$^{23}$

In any event, it is clear that Brooks is inconsistent with the Court's own position on the privilege. In 1970, five years after Louisell's article, the Court resolved the question that had troubled Louisell by holding in Williams $v$. Florida ${ }^{24}$ that a state may constitutionally compel a defendant to submit to pretrial discovery and to make a pretrial disclosure to the prosecution of his trial defenses. Although the Court subsequently decided Brooks without even mentioning Williams, I think I can show that as far as the privilege against self-incrimination is concerned, the two cases are identical. Consequently, if the Court ineans to adhere to its decision in Williams (as it shows every intention of doing), ${ }^{25}$ one of two conclusions must follow: either Brooks was

narrower view of the privilege against self-incrimination. See Lakeside v. Oregon, 98 S. Ct. 1091 (1978). See also id. at $1097 \mathrm{nn} .3-5$ (Stevens, J., dissenting).

15. 406 U.S. at 612 , quoting from Powell v. Alabama, 287 U.S. 45, 69 (1932).

16. 406 U.S. at 612 .

17. Id. at 613 .

18. Louisell, Criminal Discovery and Self-Incrimination: Roger Traynor Confronts the Dilemma, 53 CALIF. L. Rev. 89, 94 (1965).

19. Id. at 95 .

20. Diamond \& Louisell, The Psychiatrist as an Expert Witness: Some Ruminations and Speculations, 63 Mich. L. REv. 1335, 1349 (1965).

21. Louisell, supra note 18 , at 95 .

22. $I d$.

23. See id. at 97 n.34.

24. 399 U.S. 78 (1970).

25. See Wardius v. Oregon, 412 U.S. 470 (1973). If I am right that Williams and Brooks are irreconcilable with respect to the privilege against self-imcrimmation and that one of the two cases 
wrongly decided and should be overruled; or, if Brooks was correctly decided, it must be based on some constitutional principle other than the privilege against self-mcrimination.

\section{A. The Opinion of the Court}

One can start with the Court's own explanation in Brooks. The Court's reasoning is simple and straightforward. The privilege against self-incrimination contams two separate prohibitions: it prohibits the state from compelling any person to make statements that can later be used against him in a "criminal case,"26 and it prohibits the state from compelling any criminal defendant to testify as a witness ${ }^{27}$ at his own trial. The Termessee statute violated this latter prohibition, the Court argued, because by pressuring a defendant to take the witness stand at the outset of his case-m-chief, it impinged upon his "constitutional right not to take the [witness] stand."28

To be sure, since the only penalty im the statute for failing to testify at that time was to prohibit the defendant from testifying thereafter, the statute exerted no self-incriminatory coinpulsion on defendants who had no desire to testify, nor on defendants who remained willing to testify at any time during the trial. ${ }^{29}$ But the statute did exert compulsion on defendants such as Donald Brooks who had not yet decided at the close of the state's case whether to take the stand in their own defense and who preferred to reserve the decision until later in the trial.

is incorrect, Brooks is probably incorrect. Brooks is the likelier candidate because although Brooks was decided subsequently to Williams, it was not as thoroughly reasoned. In other words, Brooks is less authoritative than Williams because the particular issue they shared in common-viz., the extent to which a person can constitutionally be compelled to accelerate the disclosure of mcriminating statements that he otherwise intends to make anyway by the close of all the evidence-was fully briefed and discussed by the Court in Williams, but not even mentioned im Brooks. Thus, in order to treat Brooks as the controlling case, one would have to conclude that the Brooks Court intended to overrule its thorough analysis in Williams sub silentio. For the proposition that Supreme Court decisions ought to be construed so as to avoid the conclusion of sub silentio overruling, see Francis v. Henderson, 425 U.S. 536, 547 (1976) (Brennan, J., dissentmg); Estelle v. Williams, 425 U.S. 501, 528 (1976) (Brennan, J., dissenting); Smith v. Allwright, 321 U.S. 649, 669 (1944) (Roberts, J., dissenting); United States v. Darby 312 U.S. 100, 104 (1941) (argument for the United States).

26. "[N]or shall [any person] be compelled in any criminal case to be a witness against himself ... ." U.S. Const. amend. V.

27. Id. For a useful summary of these two elements of the privilege, see C. MCCoRMICK, EvidENCE 248-49 (2d ed. 1972).

28. 406 U.S. at 611 n.5.

29. The Brooks statute can liave no coercive effect on a defendant who maintains no desire whatever to testify on his own belialf because the sanction, forcing lim to remain silent, is precisely what lie wants to do anyway. By the same token, the statute cannot operate to coinpel self-mcrimination by a defendant who mamtains a firm desire to testify at one time or another, because whatever incriminating testimony he gives at the outset of the defense is testimony he eventually would give anyway. See State v. Amos, 262 N.W.2d 435 (Minn. 1978). Thus, the statute generally (though, perhaps, not exclusively) exerts its coercive effect on defendants who are uncertam at the outset of their case as to whether to take the witness stand and who would prefer to reserve the decision until later. 
The statute compelled such defendants to be witnesses against theinselves, because it made it "costly" for them not to testify as the first witness for the defense. The compulsion, or "cost," consisted of the threat that if they did not testify as the first witness for the defense, they would pay "the price" of being kept "off the stand entirely":

[A] defendant may not know at the close of the State's case whether his own testimony will be necessary or even helpful to his cause. Rather than risk the dangers of taking the stand, he might prefer to remain silent at that point, putting off his testimony until its value can be realistically assessed. Yet, under the Tennessee [statute], he cannot make that choice 'in the unfettered exercise of his own will.' [The statute] exacts a price for his silence by keeping him off the stand entirely unless he chooses to testify first. This, we think, casts a heavy burden on a defendant's otherwise unconditional right not to take the stand..$^{30}$

\section{B. The Views of the Dissenters}

The dissenting Justices challenged the majority on two grounds, neither of which is persuasive. First, they argued that Brooks had no grounds to complain about being coinpelled to be a "witness against himself," because he never took the witness stand. Thus, the dissenters distinguished between a hypothetical defendant who responds to pressures of the statute by regretfully taking the witness stand, and a defendant (like Brooks) who responds by regretfully standing silent. While the former defendant might be able to say that the statute had the effect of compelling him to become a witness against himself, Brooks was in precisely the opposite position. Far froin being compelled to take the witness stand at a time when he would have wished to remain silent, Brooks was prohibited from taking the witness stand at a time when he wished to testify. As Justice Rehnquist put it for the dissenters:

While it is possible that this statute ... might in another case raise issues bearing on the privilege against self-incrimination, its application in this case certainly has not done so. Petitioner Brooks never took the stand, and it is therefore difficult to see how his right to remain silent was in any way infringed by the State. Whatever may be the operation of the statute in other situations, petitioner cannot assert that it infringed his privilege against self-incrimination-a privilege which he retained inviolate throughout the trial. ${ }^{31}$

This arguinent is not only misleading, it is fundamentally misconceived. It assumes that the privilege against self-incrimination can never be violated unless a defendant responds to forbidden coinpulsion by actually inaking an incriminating statement or actually taking the witness stand over his objection. Nothing could be further from the

30. 406 U.S. at 610 (footnotes omitted).

31. Id. at 617 (Rehnquist, J., disseuting) (emphasis in original). 
truth. The privilege prohibits the state from putting a person to the cruel choice of either becoming a witness against himself or suffering a penalty for remaining silent. Accordingly, the constitutional imterests of a defendant who has been put to such a choice are violated regardless of whether he responds to the dilemma by taking the witness stand over his objection or by suffering a penalty for remaming silent. Whichever his response, he suffers constitutional injury because he should never be put to the choice in the first place. ${ }^{32}$ In other words, there is a relationship of equivalence between penalties and compulsion. A "penalty" on the privilege against self-incrimination is the kind of illicit pressure on a defendant to become a witness agamst himself which, if it is effective as a threat, would "compel" him to take the witness stand over his objection. ${ }^{33}$

To illustrate this point, assume that a state creates the dilemma in its classic forin. It adopts a statute that requires all defendants to testify as witnesses for the defense, upon penalty of contempt. The dilemma forces a defendant to respond in one of two ways, each of which causes constitutional injury: either he inust take the witness stand and run the risk that he will incriminate himself, or he must remain silent and be punished for doing so. Assume that he responds by choosing to remain silent, and is held im criminal contempt and sent to jail. Do the dissenters really mean to say that the defendant has no fifth amendment grievance in that case? Do they really inean that a defendant who stands on his right to remam silent, and is punished for doing so, has no grounds to complain?

The answer can be found in Malloy v. Hogan. ${ }^{34}$ The defendant there was subpoenaed to testify under oath about certain "alleged gambling and other criminal activities in the county." ${ }^{35} \mathrm{He}$ refused to an-

32. It is important to distinguish in this connection between the nonexistence of an injury on the one hand, and its existence but subsequent loss through waiver on the other. A constitutional injury exists whenever a defendant is placed in a forbidden dilemma, whatever his response. But it does not follow that he is always free to choose whichever response he prefers. On the contrary, when a person is put in the forbidden "trilemma" of self-incrimination, contempt, or perjury, the preferred response is to remain silent, and he will sometimes be deened to have waived his constitutional claim if he responds to the trilemma either by making incrimmating statements or by committing perjury. See text at notes $38-40$ infra.

33. This principle is illustrated by a line of cases in which public employees wcre put to the choice between either answering incriminating questions or being discliarged from einployinent. The Court concluded that the employees had been placed in the kind of dilemma that is prolibited by the privilege. Accordingly, the employees were leld to have suffercd constitutional injury however they responded to the dilemma. Those employees who responded by making incrininating stateinents were held to lave been "coerced" into becoining witnesses against themselves, e.g., Garrity v. New Jersey, 385 U.S. 493, 500 (1967); those who responded by remaining silent and being discharged were held to have suffered a "penalty" for asserting the privilege, e.g., Gardner v. Broderick, 392 U.S. 273, 279 (1968).

34. 378 U.S. 1 (1964).

35. Id. at 3 . 
swer the court's questions on the ground that his answers might tend to incriminate him and, as a consequence of his decision to remain silent, he was held in contempt and committed to prison. The Supreme Court reversed, holding that the defendant had a right not to answer the questions-and, therefore, a right not to be punished for remaining silent-because his answers might have mcriminated him. Thus, the Court implicitly rejected the peculiar notion (propounded by the dissenters in Brooks) that a defendant wlio refuses to become a "witness against himself' has no grounds to complain about being punished for asserting his right to remain silent.

To be sure, it can be argued that the choice in Brooks is distmguishable from the dilemma described above. Indeed, one of the purposes of this Article is to show that the Brooks statute did not create the kind of dilemma that is prohibited by the fifth amendment. In that event, however, a defendant would lack constitutional grounds to complain, even if he responded to the dilemma by taking the witness stand. ${ }^{36}$ Conversely, if the dilemma in Brooks was of a kind prohibited by the privilege (as the dissenters in Brooks were prepared to assume), then a defendant would suffer constitutional injury whether he responded to the dilemma by taking the witness stand or by remaming silent. ${ }^{37}$

If anything, the defendant's silence im Brooks was the constitutionally preferred response, because if he had responded to the Tennessee statute by taking the stand as the first witness for the defense, he might have been deemed to have waived his fifth amendment objection. ${ }^{38}$

36. See Berger, Man's Trial, Woman's Tribulation: Rape Cases in the Courtroom, 77 Colum. L. REv. 1, 76 (1977) ('if the threat of preclusion does not 'compel,' neither should its infiction 'penalize'"). In Lakeside v. Oregon, 435 U.S. 333 (1978), for example, the state followed the practice of giving an exphcit instruction to the jury not to draw an inference from the defendant's refusal to take the witness stand. The defendant in Lakeside argued that this practice placed him in an unconstitutional dilemma between taking the witness stand and running the risk of selfincrimmation on the one hand, and remaining silent and allowing the judge to bring his silence to the jury's attention on the other. The Court rejected the argument, holding that the judge's instruction to the jury did not provide the kind of "pressure" on the defendant to take the witness stand that is "impermissible" imder the privilege. 435 U.S. at 339. Consequently, since the defendant in Lakeside was not placed in an unconstitutional dilemma, it unade no difference how he responded. In either event-whether he responded by remaining silent and suffering the instruction (as was the case in Lakeside), or whether he responded by reluctantly taking the witness stand over his objection-he had no constitutional grounds to complaim. This is so because to say that it is not unconstitutional to place a person in a particular dilemma means that his responses to the dilemma cannot be deemed to be induced unconstitutionally.

37. See note 33 supra. See also Nakell, Criminal Discovery for the Defense and the Prosecution-The Developing Constitutional Considerations, 50 N.C. L. REv. 437, 516 n.382 (1972) (with respect to the impact of the preclusion sanction on the privilege against self-incrimination, it is "fortuitous" whether a defendant responds by remaining silent and later wishing he had testified, or by testifying and later wishing he had reinamed silent).

38. See generally Garner v. United States, 424 U.S. 648 (1976). See also United States v. Wong, 431 U.S. 174, 178-79 (1977) (a witness who is unconstitutionally forced to choose between 
Generally, if a defendant has the time and opportunity to challenge the legality of compulsion before suffering its effects, he is expected to proceed by remaining silent and by litigating his right to do so, rather than by becouning a witness against himself; ${ }^{39}$ otherwise, if he were free to respond by making incriminating disclosures without any peril to himself, he could effectively grant himself immunity and thereby deprive the prosecution of the opportunity to decide whether his testimony is sufficiently desired to deserve a grant of immunity. ${ }^{40}$ In responding to the Tennessee statute by remaining silent, therefore, the defendant in Brooks may well have exercised the only option available for preserving his fifth amendinent claim.

Second, the dissenters argued that the statute in Brooks did not put the defendant to a prohibited choice, because the sanction it imposed on a defendant for refusing to take the witness stand is not the kind of sanction that is prohibited by the privilege. The Tennessee statute provided for what has been called a "preclusion sanction." 41 That is, the statute provided that as a sanction for a defendant's refusal to take the stand at the close of the government's case, he was to be "precluded" from thereafter taking the stand in his own defense. While recognizing that the preclusion sanction put the defendant to a "diffcult choice," 42 the dissenters denied that the choice was of "constitutional dimension." 43 Specifically, they argued that this preclusion sanction exerted no compulsion on the defendant to testify. In their own words:

Petitioner was clearly not subjected to the obvious compulsion of being held in contempt for his silence, as in Malloy v. Hogan, 378 U.S. 1 (1964), nor did the Tennessee procedure subject him to any other significant compulsion to testify other than the compulsion faced by every defendant who chooses not to take the stand-the knowledge that in the absence of his testimony the force of the State's evidence may

"incriminatory truth" and "falsehood" has a fifth amendment right to remain silent, but loses his fifth amendinent claim if he responds by means of a falsehood).

39. See United States v. Kordel, 397 U.S. 1, 7-10 (1970).

40. See Garner v. United States, 424 U.S. 648, $658 \mathrm{n} .11$ (1976). Sometimes, of course, the pressures of a dilemma are such that a person cannot reasonably be expected to reflect upon his options. Thus, if a defendant is tortured by the police to make a confession, he cannot reasonably be expected to make a calm assessment of his alternatives or to recognize that silence is the preferred response. See id. at 657-58. As Justice Holmes put it in his inimitable fashion, "Id]etached reflection cannot be demanded in the presence of an uplifted knife." Brown v. United States, 256 U.S. 335, 343 (1921).

41. The term "preclusion sanction" seems to have been comed by the author of Note, The Preclusion Sanction: A Violation of the Constitutional Right to Present a Defense, 8I YALE L.J. 1342 (1972). The term has since been adopted by the Supreme Court. United States v. Nobles, 422 U.S. 225, 241 (1975).

42. 406 U.S. at 614 (Burger, C.J., dissenting).

43. Id. at 615 . 
lead the jury to convict. ${ }^{44}$

The validity of this argument depends upon low broadly it is stated. Taking the proposition in a narrowly stated form, one would argue that the preclusion sanction was valid in the particular and limited context of the Tennessee statute, because the sanction liad no effect on defendants except to compel them to decide at the close of the state's case what they would eventually be compelled to decide anyway-whether or not to take the witness stand and testify in their own defense. This limited form of the argument has great force. Indeed, as we shall later see, it is an argument the Court has already adopted in a related line of cases.

The argument becomes untenable, however, if it is broadened to mean that a preclusion sanction can never violate the privilege agamst self-incrimination because the "compulsion" sucl a sanction creates can never be sufficiently significant to assume constitutional dimension. Take, for example, a state statute providing that a defendant who asserts the privilege as a ground for refusing to answer questions put to him by the police or grand jury shall be forever "precluded" from thereafter testifymg in his own defense at trial. Or assume that the state imposes this form of preclusion on any person who can be shown ever to have asserted the privilege against self-incrimination in the course of an official imvestigation. Surely the Court would invalidate such statutes on the ground that they impose an impermissible burden on a defendant's assertion of the privilege. ${ }^{45}$ If so, then it follows that the preclusion sanction-like the sanctions of contempt, loss of public employment, loss of political party position, and loss of the right to practice law ${ }^{46}$ - can be a sufficiently significant form of compulsion to fall within the prohibitions of the privilege.

The most nearly analogous case to illustrate the point is Griffin $\nu$. California, ${ }^{47}$ in which the Court invalidated a state statute permitting the prosecutor and trial judge to comment at trial on the defendant's refusal to testify in his own defense at trial. The Court did not deny that a rational inference might be drawn from a defendant's refusal to take the stand; nor did it deny that such an inference nnight have probative value. ${ }^{48}$ Rather, the Court invalidated the inference on the ground

44. Id at 614 .

45. See Note, Prosecutorial Discovery Under Proposed Rule 16, 85 HARv. L. Rev. 994, 1006 (1972).

46. See, e.g., Malloy v. Hogan, 378 U.S. 1 (1964) (contempt); Garrity v. New Jersey, 385 U.S. 493 (1967) (public employment); Lefkowitz v. Cunningham, 431 U.S. 801, 807-08 (1977) (loss of political party position); Spevack v. Klein, 385 U.S. 511 (1967) (disbarment of an attorney).

47. 380 U.S. 609 (1965).

48. Indeed the Court has simce held a probative inference can be drawn from a witness' assertion of the privilege. Baxter v. Palmigiano, 425 U.S. 308, 316-20 (1976). One would not have supposed that any intelligent doubt on this issue could survive the publication of Professor John 
that "it cuts down on the privilege [against self-incrimination] by making its assertion costly." 49 The same is also true of the preclusion sanction in Brooks, and for precisely the same reason. Each device has the effect of making it easier for the prosecution to obtain a conviction at trial by enhancing the strength of the state's case. By raising an inference from the defendant's silence, the comment in Griffin adds an additional itern of incriminating evidence to the state's case at trial; similarly, by precluding the defendant froin taking the stand, the preclusion sanction subtracts an item of exculpatory evidence from the defendant's case-in-chief. In each case, the "cost" to the defendant of remaining silent is the increased likelihood that he will be found guilty at trial. Accordingly, if the comment in Griffin was an imperinissible "penalty"50 on the defendant's assertion of the privilege, so, too, there inust be cases in which the preclusion sanction also operates as a penalty. ${ }^{51}$

Noonan's perceptive and wholly persuasive analysis of the issue. See Noonan, Inferences From the Invocation of the Privilege Against Self-Incrimination, 41 VA. L. REv. 311 (1955) (discussing the nature and probative value of inferences from assertions of the privilege both by criminal defendants and by witnesses).

49. 380 U.S. at 614.

50. Id.

51. There is still another version of the argument that should be mentioned. The preclusion sanction does not violate the privilege, so the argument goes, not because the sanction is "insignificant," but rather because it is not the kind of sanction that conflicts with the values underlying the privilege. The purpose of the privilege, after all, is to enable a defendant to remain silent. As long as the preclusion sanction operates to prevent a defendant from testifying in his own behalf, it can never be said to violate the value of allowing him to remain silent. Indeed, in that respect the preclusion sanction is not only congenial to the privilege, it actually reinforces the privilege by prohibiting the defendant froin becoming a witness against himself. As an illustration, consider the practice at cominon law of prohibiting a defendant from ever taking the witness stand in his own defense. See note $84 \mathrm{infra}$. It is self-evident that a categorical disqualification of that kind can nevcr violate the privilege. If so, then a rule bike the preclusion sanction in Brooks, which selectively operates to preclude a defendant from becoming a witness against himself, would not appear to violate the privilege either.

The fallacy in the previous argument is its analogy to an absolute ban on the right of a defendant to testify in his own behalf. Of course it is truc that an absolute disqualification of the kind practiced at common law could never be hcld to violatc the privilege, because the right of a defendant to remain silent can hardly be violated by a rule that requires that he remain silent. But the Tennessee statute in Brooks was not a rule of that kind. On the contrary, the Tennessee statute gave the defcndant a choice at the outset of his case between taking the witness stand on the one hand or exercising his right to remain silent on the other. Yet by threatening to preclude the dcfendant from ever testifying thereafter, the statute structured the defendant's choice at that point in time in a fashion that would not have occurred if he had been free to testify at any time during the trial.

The dissentcrs in Brooks were prepared to assume that if a defendant responded by taking the witness stand over his objection, he could later argue that he was "coerced" by the threat of preclusion into becoming a witness against himself. Yet if that is true, then so is the converse; that is, if a defendant responded by remaining silent, he should equally well be able to argue that the imposition of the preclusion sanction at the later stage of the trial "penalized" him for making a decision to remain silent that was legitimate and constitutionally protected at that point in tine. In other words, if it is true that the defendant had a constitutional right to inake an unpressured 


\section{The Analogy to Williams v. Florida}

The better argument agamst the majority in Brooks is not that the preclusion sanction is valid in every conceivable case, but that the sanction was valid in the context of the Tennessee statute because it had no effect on a defendant except to accelerate a decision that he would eventually be coinpelled to make anyway. The argument, in capsule form, proceeds as follows: (1) In the absence of a procedure for de novo factfinding following the verdict, ${ }^{52}$ every defendant inust make a final decision at some point before the close of all the evidence whether to testify in his own behalf; (2) in making that decision, a defendant will inevitably be influenced by his assessment of the strength of the state's case and of the likelihood that lie will be convicted if he does not present evidence on his own behalf; (3) the coinbimation of these two factors-the strengtli of the state's case and the absence of a procedure for de novo factfinding following the verdict-may constitute a form of "compulsion" on a defendant to testify before the close of the evidence, but it is not a form of coinpulsion that is prohibited by the fifth amendinent; (4) the Tennessee statute in Brooks was constitutional because it inerely accelerated the timing of a decision that the defendant could constitutionally be "coinpelled" to make before the close of all the evidence. In short, the statute merely required the defendant to decide at the close of the state's case what he would eventually have to decide anyway. As Chief Justice Burger stated the argument for the dissenters: '[ $t]$ he only 'burden' cast on the defendant's choice to take the stand . . . is the burden to make the choice at a given point in time. That the choice might in some cases be easier if made later is hardly a matter of constitutional dimension." 53

For readers who may not have noticed, this is precisely the arguinent the Court had already accepted in the earlier case of Williams $v$.

decision at the outset of his case to remain silent, then he could not constitutionally be made to suffer a detriment for deciding to remain silent at that time.

52. This pressure on a defendant to inake an irrevocable decision as to whether to testify in his own defense does not arise in jurisdictions in which a defendant has a right to a trial de novo following the verdict, because in those jurisdictions the defendant can have it both ways. He can withhold his own testimony in order to ascertain what the verdict would be without it. If he is satisfied with the initial verdict, he can allow it to stand. Conversely, if he is dissatisfied and feels that the verdict would come out differently if he had testified, he may demand a trial de novo at which he can then testify in his own behalf. For examples of jurisdictions that permit a defendant to demand a trial de novo, see Ludwig v. Massachusetts, 427 U.S. 618 (1976); North v. Russell, 427 U.S. 328 (1976); Colten v. Kentucky, 407 U.S. 104 (1972).

This aspect of the problem would have interested David Louisell, because he recognized it to be a characteristic feature of the American judicial systein (attributable to the role of trial by jury) that hitigants generally have no opportunity for de novo factfinding on appeal, and that this lack of opportunity causes distortions that do not exist in judicial systcms that allow the factual record to remain open on appeal. See D. Louisell \& G. HAZARD, supra note 1, at 1222; Louisell \& Degnan, Rehearing in American Appellate Courts, 44 CALIF. L. REv. 627, 629 n.8, $631-32$ (1956).

53. 406 U.S. at 615 (Burger, C.J., dissenting). 
Florida. ${ }^{54}$ The statute in Williams required defendants desiring to rely on an alibi defense at trial to disclose the names of their ahbi witnesses to the prosecution in advance of the trial, and further provided that as a sanction for failing to make the pretrial disclosure, defendants could be precluded from calling alibi witnesses at trial. The defendant in Williams challenged the statute on the ground that it violated his privilege against self-incrimination. Specifically, he argued that the preclusion sanction had the effect of compelling him to make pretrial disclosures to the prosecution that might later be used agamst him at trial. $^{55}$

The Court rejected the argument, holding that "at most"56 the notice-of-ahbi statute merely compelled the defendant "to accelerate the timing"57 of a decision he could eventually be compelled to make anyway. The Court recognized that given "the strength of the State's case," 58 a defendant may often be "forced" 59 to call witnesses and to take the witness stand himself, and that in domg so he may provide evidence (or leads to evidence) that will be used against him during the trial. But the fifth amendment does not protect defendants from "that kind of pressure": 60

The defendant in a criminal trial is frequently forced to testify himself and to call other witnesses in an effort to reduce the risk of conviction. When he presents his witnesses, he must reveal their identity and submit them to cross-examination which in itself may prove incriminating or which may furnish the State with leads to incrimimating rebuttal evidence. That the defendant faces such a dilemma demanding a choice between complete silence and presenting a defense has never been thought an invasion of the privilege against compelled self-incrimination. The pressures generated by the State's evidence inay be severe but they do not vitiate the defendant's choice to present an alibi defense ..., even though the attempted defense ends in catastrople for the defendant. However 'testimonial' or 'incriminating' the abibi defense proves to be, it camrot be considered 'compelled' within the ineaning of the Fifth and Fourteenth Amendnents. ${ }^{61}$

Since a defendant can be forced by "the strength of the State's case"62

54. 399 U.S. $78,80-86$ (1970).

55. The Williams Court did not distinguish between the prosecution's use of the disclosures in its case-in-chief and the more limited use of such disclosures to rebut the defendant's evidence, and it seems unlikely it ineant to draw any such distinction. See note 198 infra. In any event, for the purpose of applying Williams to Brooks, it makes no difference. See note 66 infra.

56. 399 U.S. at 85.

57. Id.

58. Id.

59. Id. at 83.

60. Id at 85 .

61. Id. at 83-84.

62. Id. at 85.

The Supreme Court has never adequately explained why it does not violate the privilege 
to make that decision before the close of all the evidence, he can also be asked to make the same decision at a pretrial stage of the proceedings, because "the pressures that bear on his pretrial decision are of the same nature as those that would induce him to call ahibi witnesses at trial: the force of historical fact beyond both his and the State's control and the strength of the State's case built on these facts." ${ }^{.63}$ In other words, the notice-of-ahibi statute in Williams was constitutional because it merely required the defendant to make a decision before trial that he could constitutionally be compelled to make at trial:

At most, the [notice-of-alibi] rule only compelled petitioner to accelerate the timing of his disclosure, forcing him to divulge at an earlier date information that the petitioner from the beginning planned to divulge at trial. Nothing in the Fifth Amendment privilege entitles a defendant as a matter of constitutional right to await the end of the State's case before announcing the nature of his defense, any more than it entitles him to await the jury's verdict on the state's case-in-chief before deciding whether or not to take the stand himself. ${ }^{64}$

As far as the privilege agamst self-mcrimination is concerned, the Court's reasoning in Williams apphed fully as well to the statute in Brooks. Indeed, one of the principal arguments advanced by the Court to support its result in Brooks was explicitly rejected by the Court in Williams. Justice Brennan emphasized in his opinion for the Court in Brooks that the defendant could not be expected to know whether his evidence would be needed before the close of the case:

Although a defendant will usually have some idea of the strength of his evidence, he cannot be absolutely certain that his witnesses will testify as expected or that they will be effective on the stand. They may collapse under skillful and persistent cross-examination, and through no fault of their own they may fail to impress the jury as honest and reliable witnesses. In addition, a defendant is sometimes compelled to call a

against self-incrimination to place a defendant in the trilemina of (a) testifymg truthfully and thereby running the risk of self-incrimination, (b) testifying falsely and thereby running the risk of prosecution for perjury, (c) or remaining silent and thereby running the risk of being convicted for failure to contradict "the strength of the state's case." To be sure, one might suppose that the "pressure" of this particular trilemma is unavoidable, and that the justification for putting a defendant to such a choice is the justification of necessity-i.e, the state's imterest in being able to prosecute those suspected of criminal wrongdoing. Obviously there is force to this supposition, but it overlooks some of the mitigating devices that might be used to reheve the defendant of the pressures of the trilemina. For one thing, a defendant might be given the choice of making an unsworn statement in his defense in lieu of testifying under oath. See Williams, Silence and the Unsworn Statement: An Accused's Alternatives to Giving Sworn Evidence, 10 MEL. U.L. REv. 481 (1976). That option would make it possible for a defendant to take the stand as a witness in his own defense without also running the risk of being prosecuted for perjury. Consequently, one could argue that the privilege against self-incrimination requires the state to provide a defendant with an option of that kind in order to relieve him of the pressures of what the Court has called the "cruel trilemina." Murphy v, Waterfront Comm'n, 378 U.S. 52, 55 (1964).

63. 399 U.S. at 85 .

64. Id. 
hostile prosecution witness as his own. Unless the State provides for discovery depositions of prosecution witnesses, . . . the defendant is unlikely to know whether this testimony will prove entirely favorable. Because of these uncertainties, a defendant may not know at the close of the State's case whether his own testimony will be necessary or even help. ful to his cause. 65

Justice Brennan's argument is not irrational; indeed, Louisell recognized the force of the argument years before. ${ }^{66}$ The defendant in Brooks was not in as knowlcdgeable a position to commit himself at the close of the government's case as he would have been if he had been allowed to wait until his other witnesses had completed their testimony. To the extent there is a lack of correlation between the decisions a defendant would nnake at the outset of his case and the decisions he would inake at the close of his case, the Tennessce statute would tend to affect a defendant in one of two ways: either it would induce a defendant to decide to take the witness stand who would have remained silent if he had been allowed to postpone the decision, or it would induce a defendant to make an irrevocable decision to remam silent who would have taken the witness stand if he had been allowed to make the decision later. In either event, the statute created pressure that would not have existed if the statute had permitted defendants to make their

65. 406 U.S. at $609-10$ (emphasis added).

66. 'The defendant's historic immunity from the need to 'show his hand' is something less since Jones than it was before." Louisell, supra note 18, at 98-99 (commenting on Jones v. Superior Court, 58 Cal. 2d 56, 372 P.2d 919 (1962), the California Supreme Court decision that the U.S. Supreme Court later rehed upon for its fifth amendment theory in Williams, see 399 U.S. at 114 (Black, J., concurring and dissenting)).

The argument here is that the problem of self-mcrimination cannot be treated as simply a matter of "timing" (399 U.S. at 85), because the timing of a defendant's decision to make a disclosure cannot be separated froin his decision on whether to make the disclosure. See Berger, supra note 36, at 78; Kessell, Prosecutorial Discovery and the Privilege Against Self-Incrimination, 4 HAST. ConST. L. Q. 855, 883 (1977); Note, Prosecutorial Discovery Under Proposed Rule 16, supra note 49, at 1003-05. But see Clintou, The Right to Present a Defense: An Emergent Constitutional Guarantee in Criminal Trials, 9 IND. L. Rev. 713, 775 (1976). This argument has led soine commentators to conclude that Williams should be read narrowly to prevent the state froni requiring a defendant "to supply a prosecutor with information likely to aid him in establishing the state's case-in-chief." Alschuler, The Trial Judge's Role in Plea Bargaining, Part 1, 76 Colum. L. Rev. 1059, 1118 n.20I (1976). Accord Nakell, supra note 37, at 497-500. Indeed, this appears to be the view that California takes of its own constitutional provision on self-incrimmation. See Allen $v$. Superior Court, 18 Cal. 3d 520, 557 P.2d 65, 134 Cal. Rptr. 774 (1976).

But even if this narrow construction is correct (which is doubtful, see note 198 supra), it is not enough to reconcile Williams with Brooks, because under even this narrow view a defendant could be required to disclose his trial defenses once the prosecution liad completed its case-inchief, viz., once the case had reaclied the stage at which the defendant in Brooks was required to make his decision on whether to take the witness stand. See Nakell, supra note 37, at 499-500, 504-05, 516 n.382. Yet in Brooks the Court concluded that a defendant cannot be required to nake his decision even at that point in time and, instead, has the right to delay his decision "until he has seen how his own case pans out." Amsterdam, supra note 4, at 405 . In sum, as far as the privilege against self-incrimination is concerned, Brooks is incousistent with even the narrowest construction of Williams. 
decision at any time before the close of all the evidence. In that sense, the Court in Brooks was correct in concluding that the statute cast a "burden" 67 upon the defendant that would not have existed if he had been free to make the decision at any time before the close of the case.

The important point is that the very same argument was explicitly raised and rejected by the Court in Williams. Precisely the same burden existed in Williams. The Williams defendant, in challenging the notice-of-alibi statute, argued that he could not be expected to know before trial whether he would present an alibi defense until he had assessed the strength of the state's case against him. As in Brooks, the defendant in Williams was called upon to make a decision at a time when he was less knowledgeable than he would have been if allowed to postpone the decision. As a result, the defendant in Williams (like the defendant in Brooks) was induced to make a decision that was different from the one he would have made had he been permitted to wait until the close of all the evidence. Indeed, the Court candidly admitted that the notice-of-alibi statute in Williams might induce a defendant to make precipitous disclosures before trial that he might later come to regret after assessing the actual strength of the state's case against him. ${ }^{68}$

Despite this recognition, the Williams Court rejected the argument in no uncertain terms. After noting that the state law in Williams provided for "liberal discovery by the defendant agamst the State" 69 and for "reciprocal discovery agamst the State,"70 the Court sustained the statute, holding that the pressures on the defendant to commit himself to a particular defense before trial were "very similar"71 and "of the same nature as those .. . [operatimg on him] at trial." ${ }^{.72}$ Consequently, one must conclude that the increniental increase in pressures operatimg on the defendant due to the acceleration of his disclosure decision, though real, were not of sufficient magnitude in Williams to violate the privilege against self-incrimination. If so, then the same conclusion also follows in Brooks, because, as between the two defendants, the greater burden (if any) was on the defendant in Williams since he was forced to make his decision at a time when he knew considerably less about the "strength of the State's case"73 than the defendant knew in Brooks. After all, the defendant in Brooks did not have to face the dilemma between disclosure and silence until he had already heard and

67. 406 U.S. at 610.

68. 399 U.S. at 84 (recognizing that a defendant who has formulated an alibi defense before trial may want to "abandon" the defense at trial).

69. 399 U.S. at 81 .

70. Id at $81,82 \mathrm{n} .11$.

71. Id at 84 .

72. Id at 85 .

73. Id. 
seen the state's entire case-in-chief; the defendant in Williams, on the other hand, was required to face the dilemma at least ten days before trial, and before hearing any witnesses for the prosecution. ${ }^{74}$ Significantly, even the dissenters in Williams were prepared to contrast the "inherent uncertainty"7s in Williams with the "certainty" the defendant has after hearing and seeing the state's case-in-chief:

When a defendant is required to indicate whether he might plead alibi in advance of trial, he faces a vastly different decision from that faced by one who can wait until the State has presented the case agamst him before making up his mind. Before trial the defendant knows only what the State's case might be. Before trial there is no such thing as the "strength of the State's case"; there is only a range of possible cases. At that time there is no certamty as to what kind of case the State will ultimately be able to prove at trial. Therefore any appraisal of the desirability of pleading alibi will be beset with guess work and gambling far greater than that accompanymg the decision at the trial itself. ${ }^{76}$

Thus, even the dissenters in Williams, who objected to requiring a defendant to disclose his defense before trial, apparently found no objection to requiring a defendant to make that decision "after the State has produced the evidence against him at trial . . .."77

\section{Some Potential Distinctions Between Brooks and Williams}

Since the reasoning of Williams applies with equal force to Brooks, the Court's reliance on the privilege against self-incrimmation in Brooks nnust have been misplaced. ${ }^{78}$ Before drawing that conclusion, however, three possible distinctions should be explored. First, the preclusion sanctions in the two cases were shightly different from one another. The sanction in Williams for a defendant's failure to disclose his alibi defense was to preclude him from thereafter calling any alibi witnesses at trial other than himself. The sanction in Brooks for the defendant's failure to take the witness stand at the close of the governinent's case was to preclude him from thereafter calling himself as a witness for the defense. Thus, it can be argued that what distinguishcs the two cases for fifth amendment purposes is that the preclusion sanction in Brooks imposes a heavier "burden" on the privilege than does the sanction in Williams.

The trouble with this argument is that it rests on the questionable

74. "The uncertainty confronting the defendant in Brooks at the time he was required to take the stand was even more aggravated in Williams because [a defendant like Williams] not only has not had a chance to see his own case unfold, but also is even more uncertain about the strengths and weaknesses of the prosecution's case." Nakell, supra note 37, at 516 n.383.

75. Id.

76. Id.

77. $I d$. at 108 .

78. See note 25 supra. 
premise that the right of a defendant to call himself as a witness for the defense is more important-and its loss, therefore, more "burdensome" - than the right of a defendant to call third persons as witnesses in his defense. This assumption finds no support in either the realities of trial litigation or in the history of constitutional procedure. When a defendant testifies on his own behalf, his credibility is regularly discounted by the factfinder for reasons of self-interest; moreover, in many cases, his credibility is further impeached by evidence of prior crimes. As a result, altliough tlie defendant may be an important witness for the defense, his value can hardly be said to exceed the total value of all other witnesses for the defense. This assessment is also reflected in the history of the sixth amendment. Tlius, while the frainers of the sixth amendment made specific provision for the production and presentation of third persons as witnesses for the defense, they made no inention of the right of the defendant to testify as a witness for the defense. Indeed, far from having a constitutional right to testify on their own behalf, federal defendants until 1878 were prohibited from testifying in their own defense. ${ }^{79}$ It is significant that as late as 1961 the Supreme Court was still reluctant to grant that a defendant had a constitutional riglit to testify on his own behalf, and it was not until 1975, and then only in dictum, that the Court was prepared to recognize the riglit. $^{80}$

To be sure, a defendant may wish to testify on his own behalf not only to get the substantive content of his testimony imto evidence, but also to give the jury a more immediate and visible impression of his person. This latter interest is significant and may even warrant in-

79. Act of Mar. 16,1878 , ch. 37,20 Stat. 30 (1878) (current version at 18 U.S.C. $\$ 3481$ (1970)). For the history of the rule that a defendant in a criminal proceeding is incompetcnt to testify as a witness, see Ferguson v. Georgia, 365 U.S. 570 (1961); Estelle v. Wright, 572 F.2d 1071, 1075-77 (5th Cir. 1978) (Godbold, J., dissenting).

80. The Court had previously said that a defendant has a right "to be heard in his defense," Snyder v. Massachusetts, 291 U.S. 97, 116 (1934), and "to offcr testimiony," In re Oliver, 333 U.S. 257,273 (1948), but it was uncertain whether that included the right not only to call third persons as witnesses in his defense, but also to call himself as a witness for the defense.

The constitutional question was presented in Ferguson v. Georgia, 365 U.S. 570 (1961), but the Court refused to pass on the question for procedural reasons. Compare 365 U.S. at 596, with id. at 601-03 (Clark, J., dissenting). It was not until Faretta v. California, 422 U.S. 806, 819 n.15 (1975), that the Court finally stated unequivocably that a defendant in a criminal case has a constitutional right "to testify on his own behalf" (dictum). Yet even now the Court renains somewhat ambivalent on the issue. See United States v. Grayson, 98 S. Ct. 2610, 2618 (1978) ("perhaps" a defendant has "a constitutional right to testify on his own behalf") (emphasis added). Cf. United States v. Ives, 504 F.2d 935, 939 n.8 (9th Cir. 1974) (collecting cases describing the defendant's interest in testifying in his own behalf as a "privilege" rather than a "right"). This slow and tentative emergence of the right to testify belies the notion that the right is more important than the well-established and explicit sixth-amendenent right of a defendant to call third persons as "witnesses in his defense." For a history of the compulsory process clause of the sixth aunendment, see Westen, The Compulsory Process Clause, 73 MICH. L. REv. 71, 75-108 (1974). See also note 206 infra. 
dependent constitutional protection. Indeed, in holding in Faretta $\nu$. California $^{81}$ that a defendant has a constitutional right to represent himself, the Court gave implicit support to the notion that a defendant has a constitutional interest in making himself the subject and focus of the proceeding. Nonetheless, even if that is true, it does not follow that a defendant's interest in calling himself as a witness is greater than his combined interest in calling all other witnesses for the defense, or that the threatened loss of the former interest creates greater "pressure" on a defendant than the threatened loss of the latter. Even in Faretta the Court recognized that a defendant, by his conduct, can lose the right to represent himself. ${ }^{82}$ Moreover, there are other ways for a defendant to make himself the focus of the proceeding besides taking the witness stand as a witness for the defense; among other things, he can always follow the path cliosen by the defendant im Faretta, and simply represent himself. In that connection, it is surely relevant that in fashioning a preclusion sanction for a defendant who fails to give pretrial notice of an insanity defense, the framers of the Federal Rules of Criminal Procedure drew no distimction between the defendant himself and other witnesses for the defense: rule 12.2 provides that as a sanction for the defendant's failure to give the required notice, a court may preclude the defendant from calling any witness, including himself, to testify on the issue. ${ }^{83}$

A second possible distinction between Brooks and Williams rests on the difference between being compelled to make disclosures and being compelled to offer evidence. The privilege against self-incrimination, so the argument goes, contaims two separate elements: (1) the right of a person not to be compelled to make incriminating statements, and (2) the right of a criminal defendant not to be compelled to take the

81. 422 U.S. 806 (1975).

82. Id. at 834 n. 46 .

83. FED. R. CRIM. P. 12.2(a). See also United States v. Winn, 577 F.2d 86, 89 (9th Cir. 1978); Bowen v. State, 263 Ind. 558, 565-66, 334 N.E.2d 691, 696 (1975) (a defendant who fails to give notice of alibi is not only precluded from calling third persons as alibi witnesses at trial, but also from taking the witness stand himself on the issue); Simos v. Burke, 41 Wis. 2d 129, 136-38, 163 N.W.2d 177, 180-81 (1968) (same). But cf. National Advisory Commission on Criminal JUSTICE STANDARDS AND GoALS, CouRTS 90-91 (1973) (although a defendant can be precluded from calling third-person witnesses as a sanction, he "should not" be precluded from taking the witness stand himself in his defense).

One could also take an intermediate position and argue that it is not an unconstitutional burden on the privilege against self-incrimimation to preclude a defendant either from calling third persons as witnesses or from calling himself as a witness, provided he retains the alternative means for presenting evidence in his defeuse. According to this argument, the preclusion sanction in Williams was constitutional because it cut off only one of the two alternatives for presenting evidence and left it open to the defendant to call himself as a witness for the defense. But if that argument is sound, it means that the preclusion sanction in Brooks was also constitutional, because while the statute in Brooks precluded the defendant froin calling himself as a witness, it left it open to the defendant to call all third persons as witnesses in his defense. 
witness stand at his own trial. What distinguishes Williams from Brooks is that Williams involved the former kind of coinpulsion while Brooks involved the latter kind. Thus, the Tennessee statute in Brooks placed a greater burden on the defendant's privilege against self-incrimination than the notice-of-alibi statute in Williams, because the Tennessee statute not only pressured the defendant to make preinature disclosures that might be incriminating, it also pressured him to actually take the witness stand as a "witness against himself."

The defect in the foregoing argument is that it implicitly rests on one of two assumptions, neither of which is justified. On the one hand, if the annount of compulsion on the defendants in Williams and Brooks was the same, then in order to argue that Brooks alone was entitled to relief, one must implicitly assume that the right of a defendant not to be compelled to take the witness stand at trial is more important than the right of a person not to be compelled to inake incriminating statements. Yet there is no reason to beheve that the former component of the privilege against self-incrimination is entitled to any greater protection than the latter. Indeed, if anything, precisely the opposite is true, because history suggests that the right of a person to be free from compulsory self-incrimination was the paradigm of the privilege, and that the right of a defendant not to take the witness stand was a subsequent and subordinate development derived from the unrelated fact that criminal defendants for inany years were not even allowed to testify in their own behalf. ${ }^{84}$ In sum, if there is any reason at all to distinguish in importance between the right of the defendant in Williams not to inake incriminating statements and the right of a defendant im Brooks not to take the witness stand, the defendant in Williams had the stronger claim.

On the other hand, if it is conceded that the two components of the privilege are of equal importance, then the argument rests on the implicit assumption that the defendant in Brooks was under greater compulsion than was the defendant in Williams. Again, there is no reason to believe that sucl was the case. Indeed, if anything, the timing and

84. See C. MCCORMICK, EVIDENCE, supra note 27, at 257; 8 J. WIGMORE, EVIDENCE \& 2268, at 406-07 (rev. ed. 1961). The reason for this is that the right of a criminal defendant not to testify as a witness at his own trial may have origmated in the desire to protect timid and nervous defendants, often uncounseled, from being imtimidated and confounded by aggressive prosecutors. See Wilson v. United States, 149 U.S. 60, 66 (1893); Clapp, Privilege Against Self-Incrimination, 10 RuT. L. REv. 541, 548-49 (1956). Accordingly, now that even indigent defendants have a constitutional right to be represented by counsel, and now that trial standards prohibit prosecutors from badgering witnesses, the original justification for this aspect of the privilege may have lapsed. $C$. J. WIGMORE, supra, \$ 2251, at 311 n.3.

This is a distinction that Louisell himself had occasion to comment npon. Louisell implied that as between the two "discrete elements" of the privilege, the right of "any person to refuse to answer incriminating questions" may be paramount, and that " $a$ defendant's right wholly to avoid questioning" may now be an anachronism. See Diamond \& Louisell, supra note 20, at 1349. 
nature of the decision in Williams created greater compulsion on the defendant than the timing and nature of the decision in Brooks. The situation in Williams was more coercive, because there the defendant was required to make his decision at a time when he knew less about the substance of the state's case against him. At the time they were required to inake their respective decisions, the defendant in Williams could only make a prediction about the nature of the state's case against him, while the defendant in Brooks had certam knowledge of the state's case-in-chief. The actual nature of the two decisions was also inore coercive in Williams because the required disclosure in Williams was not limited to evidence which the defendant had already decided for certain to present at trial (as was the case in Brooks), but rather extended to any alibi evidence that he might later want to present in his defense at trial. ${ }^{85}$ Thus, the scope of the incriminating disclosure tended to be broader in Williams. In sum, as far as the privilege against self-incrimination is concerned, the statutory requirement im Brooks of tlie defendant to take the witness stand was no more abusive than the requireinent in Williams that the defendant make potentially incriminating disclosures.

Finally, one might try to distinguish the two cases on the ground that tle statute in. Williams provided the defendant with reciprocal discovery of the prosecution. The Court in Williams placed considerable

85. The Court in Williams made a point of emphasizing that the notice-of-alibi statute did not require the defendant actually to place any item into evidence, but rather left it to the defend. ant at trial to decide whether to put on an alibi defense. As the Court said, "we simply are not confronted with the question of whether a defendant can be compelled im advance of trial to select a defense froin which he can no longer deviate." 399 U.S. at 84 n.15. As far as the privilege against self-mcrimination is concerned, however, it is unclear why the distinction made by the Court should make any difference. The purpose of the privilege, after all, is to protect the defendant from being compelled to make incriminating disclosures that might later be used against him at trial. See Scott v. Smith, 519 P.2d 774 (Alas. 1974); Kesell, supra note 66, at 888-91. Consequently, the violation occurs at the time the defendant first diseloses the information to the prosecution and remains unaffected by whether or not the defendant later places those same items of information into evidence in his defense. In other words, the controlling factor is not what the defendant later does with the information, but what the prosecution does with the information once it has obtamed it. Accordingly, the focus should be on the scope of the initial disclosure, because the broader the initial disclosure, the more likely the government will obtam information that it later can use against the defendant. To that extent, the statute in Williams imposed a greater burden on the privilege than the statute in Brooks, because by requiring the defendant to disclose every item of evidence that he might conceivably want later to introduce at trial (as opposed to only those itens of evidence that he had already committed himself to introduce at trial), the Williams statute imposed a broader scope of disclosure. This is a point that Justice Black made in his dissenting opmion in Williams:

[I]n most situations defendants with any possible thought of pleading alibi are in effect compelled to disclose their intentions in order to preserve the possibility of later raising the defeuse at trial. Necessarily few defendants . . . will be willing to risk the loss of that possibility by not disclosing the alibi. Clearly the pressures on defendants to plead an ahbi created by this procedure are not only quite different from the pressures operating on the trial itself, but are in fact significantly greater.

399 U.S. at 110 (Black, J., concurring and dissenting) (elnphasis added). 
emphasis on this feature, implying that it would look with disfavor on a statute that required a defendant to give notice of his alibi witlout also providing him with reciprocal discovery of the prosecution. Indeed, three years later, in Wardius $v$. Oregon, ${ }^{86}$ the Court fulfilled the implication by invalidating a notice-of-alibi statute on the ground that it failed to provide for reciprocal discovery. Tlus, while the importance of reciprocal discovery was still unclear at the time Brooks was decided, it subsequently appeared that the presence of reciprocity was an indispensable element in the decision in Williams.

In order to decide whether Brooks was defective for lack of reciprocity, one inust first identify the reason why the Court in Williams considered reciprocity so important. There are several possibilities. For one, insofar as the reciprocity provision in Williams was part of an extensive scheme of pretrial discovery that enabled a defendant to gain almost as much knowledge of the state's case before trial as he would eventually obtain at trial, the reciprocity provision may have been important to the Court in Williams as a furtler indication that the defendant was under no greater "pressure" 87 to disclose his alibi before trial than he eventually would have been under at trial. In other words, the reciprocity provision in Williams may have helped place the defendant in approximately the same position before trial that he would otherwise have occupied at the close of the state's case, and thus inade it possible for the Court in Williams to conclude that the defendant was not being compelled to do anything more than lie eventually would be compelled to do at trial. However, if that is the rationale for reciprocity, it does not explain Brooks, because as we have already seen, the defendant in Brooks was not asked to make any decision at all until he had already seen and heard the state's entire case-in-chief. Thus, if the rationale of reciprocity is to approximate the position the defendant would find himself in at the close of the state's case, it is a pale imitation of the position the defendant in Brooks already enjoyed by the time lie was called upon to inake his decision.

Alternatively, it can be argued that the rationale of reciprocity is that it helps maintain the traditional balance of advantage that exists between the prosecution and the accused by ensuring that the defendant be given a compensating advantage to offset wliat the prosecution gams by the notice-of-alibi statute. This argument is more abstract than most, but it has some force. ${ }^{88}$ After all, the modern criminal trial

86. 412 U.S. 470 (1973).

87. 399 U.S. at 85. Professor Nakell makes this point about the relationship of pretrial discovery to the requireinent that a defendant disclose his alibi defense in advance of trial. Nakell, supra note 37 , at 505-06.

88. It is this notion of "faimess-as-mutuality" that the Court was referring to in Wardius when it said that "discovery must be a two-way street." 412 U.S. at 475 . In the Court's words: "It is fundainentally unfair to require a defendant to divulge the details of his own case while at the 
has evolved into an adversary procedure that depends for its accuracy on inaintaining a certain balance of advantage between the prosecution and the accused. When the state creates an innovation (like a noticeof-alibi statute) that gives new and added power to one party to the adversary process, it threatens to disturb the traditional balance of advantage. To protect against disequilibriun of this kind, the Court requires that when certain advantages are given to one party, reciprocal advantages must be given to the other. Accordingly, so the argument goes, before the state can require a defendant to disclose his alibi witnesses in advance of trial, it inust give him the right to demand that the prosecution disclose its rebuttal witnesses in return.

This argument does not provide a basis for distinguishing Brooks from Williams because the policy of maintaining a ininimum balance of advantage between the prosecution and the accused was fully served in Brooks. The statute in Brooks imposed the same obligation on the prosecution as on the accused: it provided that if the prosecution wished to call the complaining witness as part of its case-inchief, it nnust call him as the first witness for the prosecution or be barred froun calling the witness thereafter. As Justice Rehnquist pointed out for the dissenters, the Tennessee statute operated "evenhandedly" 89 because it applied "the same rule" 90 to both the prosecution and the defense. Whatever the rationale for reciprocity in Williams, therefore, it appears to have been fully satisfied in Brooks.

In conclusion, if the notice-of-alibi statute in Williams did not violate the privilege of self-incrimination, then neither did the Termessee statute in Brooks. To illustrate this conclusion, assume that the Tennessee statute was amended to conform to the scheme in Williams. Instead of putting a defendant to the choice between disclosing the substance of his personal testimony at the close of the state's case or forgoing the opportunity to testify later, the statute is amended to require the defendant to inake the choice even earher: the statute now provides that defendants who desire to testify on their own behalf at trial shall disclose the substance of their proposed testimony ten days in advance of trial, or be precluded from taking the witness stand at trial. Presumably this lyypothetical statute would pass the Court's test in Williams, because the statute does nothing but "accelerate"91 a decision that the defendant eventually will be compelled to inake at trial. Yet as far as the privilege against self-incrimination is concerned, the

same time subjecting him to the hazard of surprise concerning refutation of the very pieces of evidence which he disclosed to the State." Id. at 476. For a discussion of the theoretical nature of this notion of fairness, see Westen, supra note 80, at 177-82. See also Berger, supra note 36, at 7882.

89. 406 U.S. at 619 (Rehnquist, J., dissenting).

90. Id.

91. 399 U.S. at 85. 
hypothetical statute is considerably more burdensome than the statute in Brooks, because the defendant in Brooks was at least permitted to postpone the disclosure until after he had seen and heard at trial the totality of the state's case against him.

\section{III}

\section{The Right to Counsel}

The Court in Brooks also based its decision on an alternative and wholly independent ground-nainely, that the Tennessee statute violated the defendant's sixth amendment right to counsel. This again is an argument that would have interested Louisell because he had great faith in the "adversary systein"92 _ a system where procedure is "litigious and contentious rather than officious and inquisitorial"93 -and because he viewed the right to counsel as an integral feature of the adversary system. ${ }^{94}$ Indeed, Louisell's interest in the role of the lawyer did not stop with the usual "utilitarian"95 concern for the "ascertaminent of truth in hitigation." 96 He was also interested in preserving the "dignity" and "intellectual honesty"97 of the practicing attoruey. Thus, in discussing the rationale for the lawyer-chent privilege, Louisell rejected the notion that the privilege was "necessary to ensure that the attorney gets all essential information,"98 and suggested, instead, that the privilege is designed to protect "the practitioner" from the "unhealthy moral state" of having to "pervert the function of counselling" by "revealing his chents' secrets."

Nonetheless, it is questionable whether Louisell would have agreed with the decision in Brooks, because the Court's reasoning in

92. D. Louisell \& H. Williams, The Parenchyma of Law 403 (1960); Louisell, Book Review, 35 Texas L. Rev. 892, 895-96 (1957). Indeed, Louisell believed that the adversary process was integral not only to the ascertainment of truth in litigation, but also to the preservation of our civil liberties. See Louisell, Book Review, 79 ScIENTIFIC MonThLY 332 (1954).

93. D. Louisell \& H. Williams, supra note 92, at 404.

94. D. Louisell \& B. Wally, Modern California Discovery $\$ 10.03$, at 586 (2d ed. 1972); Louisell, Discovery and Pre-Trial Under the Minnesota Rules, 36 MiNN. L. Rev. 633, 636 (1952); Louisell, Book Review, 35 Texas L. Rev. 892, 896 (1957).

95. Louisell, Confidentiality, Conformity and Confusion: Privileges in Federal Court Today, 31 TUL. L. REV. 101, 111 (1956).

96. D. LOUISELL \& B. WALLY, supra note 94, at 593.

97. Louisell, Discovery and Pre-Trial Under the Minnesota Rules, 36 MINN. L. REv. 633, 637 (1952).

98. Louisell, supra note 95 , at 112 .

99. Id. (quoting with approval froin Wigmore). See also D. Louisell \& B. WaLlY, supra note $94, \S 10.04$, at 574 :

It is commonly assuined by American courts that the justification for the lawyer-client privilege is the need to induce the client to make full and frank disclosure of all relevant facts to his attorney. [A] more fundamental basis for the privilege [is] that the compnlsory disclosure by an attorney of facts revealed to him by his client in confidence would ... be morally reprehensible.

(emphasis added). 
that case was fundamentally different from its prior right-to-counsel opinions. Generally, the issue in right-to-counsel cases is whether the defendant is entitled to access to counsel: Is the defendant entitled to the assistance of retained counsel? ${ }^{100}$ Is he entitled to the appointment of counsel at the state's expense? ${ }^{101}$ Is he entitled to the assistance of counsel at a particular stage in the proceedings? ${ }^{102}$ Is he entitled to a good faith judgment from his lawyer about his rights under the prevailing rules of law? ${ }^{103}$ However, none of these questions was at issue in Brooks, because it was conceded there that the defendant had a right to the assistance of counsel at all stages of the trial, and a right to obtain his lawyer's good faith judgment about his rights and options under the prevailing rules of law. Rather, the question in Brooks was whether the defendant's right to the assistance of counsel included the right to insist that his attorney be allowed to change the rules by which the case was tried.

The defendant, Brooks, argued that the Tennessee statute deprived him of "the guiding hand of counsel,"104 by requiring his lawyer to decide whether to call the defendant as a witness for the defense before the lawyer had "an opportunity to evaluate the actual worth of [his other] evidence," 105 and by prohibiting the lawyer from thereafter calling his client as a witness, "even though as a matter of professional judgnent his lawyer might want to call him later in the trial." 106 The Court agreed, holding that "the accused and his counsel may not be restricted in deciding whether, and when in the course of presenting his defense, the accused should take the stand." 107

There are several problems with the Court's approach, not the least of which is that the Court has since repudiated it entirely. ${ }^{108}$ First of all, the Court's argunient goes too far, because if extended to its natural himits, the argunient would invalidate "countless other rnles of evidence and procedure" 109 that prevent defense counsel from controlling the criminal trial in the way he would if he had rulemaking au-

100. See, e.g., Gagnon v. Scarpelli, 411 U.S. 778, 783 n.6 (1973) (reserving the question whether a defendant who can afford to hire an attorney has a right to insist on being able to retain counsel to represent him in a parole revocation proceeding).

101. See, e.g., Ross v. Moffitt, 417 U.S. 600 (1974).

102. See, e.g., Gerstein v. Pugh, 420 U.S. 103, 120-22 (1975).

103. See, e.g., Geders v. United States, 425 U.S. 80 (1976); Maness v. Meyers, 419 U.S. 449, 470 (1975) (Stewart, J., concurring).

104. Powell v. Alabama, 287 U.S. 45, 69 (1932).

105. 406 U.S. at 612.

106. Id.

107. Id. at 613 (emphasis added).

108. See note 190 infra.

109. 406 U.S. at 616 (Burger, C.J., dissenting). Interestingly, it is precisely this "swceping" nature of the argument that inakes it appealing to soine commentators. Amsterdam, supra note 4, at 405 . 
thority. Indeed, in that sense, the Court's reasoning "stands on its head the traditional understanding of the defendant's right to counsel." 110 Instead of assuming that the purpose of counsel is "to advise the accused as to various choices available to him within the limits of existing state practice and procedure," 111 the Court assumes that the purpose of counsel is to formulate-or "legislate"-the rules that should govern the conduct of criminal trials. As the dissenters put it:

The Court's holding that the Tennessee rule deprives the defendant of the "guiding hand of counsel" . . . amounts to nothing more than the assertion that counsel may not be restricted by ordinary rules of evidence and procedure in presenting an accused's defense if it might be more advantageous to present it in soine other way. A rule forbidding defense counsel to ask leading questions of the defendant when he takes the stand may restrict defense counsel in his options and may in many cases bear only remote relationship to the goal of truthful testimony. Yet no one would seriously contend that such a umiversal rule of procedure is prohibited by the Constitution. ${ }^{12}$

Second, and ironically, the Court's reasoning in Brooks does not go far enough. The premise underlying the Court's decision is that there is something very important to the defendant about deciding "at what point durmg the presentation of his case to take the [witness] stand"113 - so important, in fact, that it is unconstitutional to prevent a defendant fron being assisted by his counsel in making that decision. Yet having based its decision on the right to counsel, the Court would be forced to deny the benefits of Brooks to all defendants who choose to forgo counsel and to proceed pro se:

Logically the benefit of today's ruling should be available to a defendant conducting his own defense who has waived the right of counsel, but since the Court insists on putting the issue in terms of the advice of counsel, rather than in terms of defense control over the timing of defendant's appearance, the application of today's holding to that situation is by no means clear. ${ }^{114}$

To be sure, one can argue that just as a defendant who is representcd by counsel is entitled to be advised by his counsel on when to take the witness stand, so, too, a defendant who represents himself is entitled to counsel himself on when to testify. But to make the argument is to expose the right-to-counsel rationale for what it really is-a fiction to conceal a substantive determination that a defendant should be able to take the witness stand any time during the course of his defense, whether he is represented by counsel or not. ${ }^{115}$

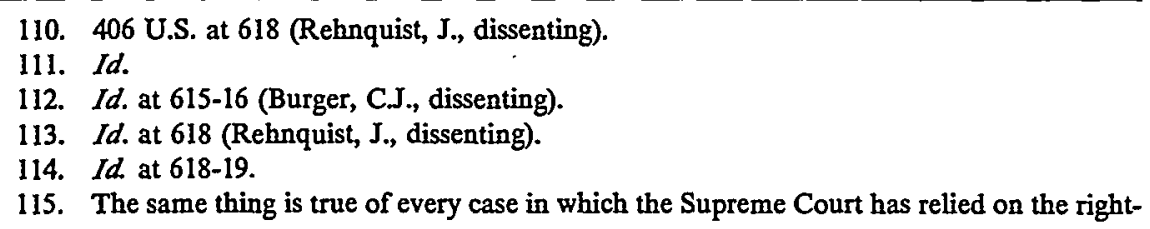


Third, as already suggested above, the right-to-counsel argument is ultimately superfluous. Brooks was not based on a procedural notion of the right to counsel that merely incorporates by reference whatever rules might otherwise exist for the conduct of criminal cases; rather, it was based on a substantive notion of the right to counsel that itself defines the kinds of trial rules a defendant is minimally entitled to. Accordingly, in order to decide whether this substantive notion of the right to counsel is violated in any particular case, one must first make a substantive determination, by some anterior standard, of what a fair trial consists of. But once that determination has been made-once it has been determined, for example, that it is unfair to require a defendant desiring to testify on his own behalf to testify as the first witness for the defense-it adds nothing to say that a contrary rule violates the right to counsel. Simce the core of the determination consists of a constitutional judgment that a defendant should be allowed to testify at any time during the course of his defense, it suffices to say that the constitutional right consists precisely of that. Once a defendant has been determined to have such a right, it is superfluous to go on to say that he also has a separate right to be counseled about his right to take the stand whenever he wishes.

This conceptual fallacy is illustrated by Herring v. New York. ${ }^{116}$ The defendant there challenged the constitutionahty of a New York statute that demed defendants the right to make a closing argument in a nonjury case. The Court agreed with the defendant, holding that the statute denied him "the assistance of counsel" 117 by prohibiting his lawyer from making a closing argument to the trial court. In coming to that conclusion, however, the Court first had to make a substantive determination that a defendant in a criminal case has a basic right to make a "final argument im a nonjury criminal trial." 118 Yet, having determined that a defendant has a basic right to make a closing argument, it was superfluous for the Court to go on to say that it violated the defendant's separate right to counsel to prohibit his lawyer from assistimg him with his closing argument. Indeed, it was not only superfluous, it was terribly misleading, because it suggested that a defendant

to-counsel provision to strike down substantive rules of trial procedure. Thus, Herring v. New York, 422 U.S. 853 (1975), can be seen as constitutionalizing the right of a defendant to make a closing argument, see 422 U.S. at 865 (Rehnquist, J., dissenting); Brooks can be seen as constitutionalizing the right of a defendant to testify in his own behalf, see Note, Right to Testify, 3 HofsTRA L.J. 839, 844 (1975); Ferguson v. Georgia, 365 U.S. 570 (1963), can be seen as constitutionalizing the right of a defendant (in the absence of an opportunity to testify as an ordinary witness) to make a sworn statement in his defense, see Westen, supra note 80, at 109-11.

116. 422 U.S. 853 (1975).

117. Id. at 865 .

118. Id. at 859 . 
who proceeded pro se would not be entitled to make a closing argument, a suggestion the Court obviously intended to avoid.

The sounder approach would have been to pierce the veil of counsel and recognize that the Court had constitutionalized an element of "the adversary fact-finding process" 119 by holding that a defendant has a constitutional right to make a closing argument- "whether through counsel or otherwise." 120

The foregoing arguments should be a sufficient response to the Court's reasoning im Brooks on the right to counsel. If more is needed, however, it can be found in the recent decision of the Court itself in Lakeside v. Oregon. ${ }^{121}$ The defendant in Lakeside challenged his conviction on the ground that the trial judge had given the jury an explicit instruction, over the defendant's vigorous objection, that the jury should draw no adverse inference from the defendant's failure to testify in his own behalf. The defendant challenged the instruction on two grounds-that the instruction imposed a burden on his fifth amendment privilege not to take the witness stand, and further, that it imposed a burden on his sixth amendment right to be assisted by counsel in controlling the strategy of his defense. The Court rejected both arguments without difficulty, but its rationale for rejecting the right-tocounsel argument is particularly pertiment here. The Court held that once the defendant's primary argument on the privilege against selfimcrimination was rejected, the right to counsel argument "falls of its own weight." 122 The argument failed because it was based on a fundamental misconception about the nature of the right to counsel: the right to counsel does not give a lawyer the substantive right to "veto"123 otherwise valid rules for the conduct of criminal trials, but rather gives him the procedural authority to advise his client about whatever substantive rights he may otherwise have under prevailing rules of constitutional and domestic law. "To hold otherwise," the Court said, "would mean that the constitutional right to counsel would be implicated in almost every wholly permissible ruling of a trial judge, if it is made over the objection of the defendant's lawyer." 124

In sum, Brooks cannot be explamed on right-to-counsel grounds. To be sure, one might be justified in concluding that the Tennessee statute in Brooks was invalid for reasons having nothing to do with the right to counsel. Indeed, one of the purposes of this Article is to show that Brooks can be explained as a demal of the defendant's "right . . .

119. Id. at 858.

120. Id. at 865 (Rehnquist, J., dissenting).

121. 435 U.S. 333 (1978).

122. Id. at 341.

123. Id.

124. Id. 
to decide at what point during the presentation of his case to take the stand." 125 But if there was such a substantive defect in the Tennessee statute, then the statute should have been invahidated directly on that ground and not on the indirect ground that the defect inhibited the effectiveness of the defendant's lawyer. Conversely, if the Tennessee statute did not violate any other provision in the Constitution, neither did it violate the right to counsel, because the counsel clause of the sixth amendinent does nothing inore than incorporate by reference whatever rules and procedures are otherwise prescribed by law for the conduct of criminal cases.

\section{IV}

\section{The Right of a Defendant to Testify IN HIS OWN DEFENSE}

So far we have explored and rejected the two arguments the Court used to support its decision im Brooks. Yet there is still a third possibility. Some commentators have argued that the Tennessee statute was invalid because it violated the defendant's constitutional "right to present a defense." 126 The argument is relatively straightforward. A defendant in a criminal case has a constitutional "right . . . to testify on his own behalf." 127 That means that if a defendant wishes to take the witness stand in his own defense at trial, he has a constitutional right to insist on being allowed to do so. The Tennessee statute innpaired the exercise of that right by prohibiting the defendant from taking the witness stand after other witnesses had testified on his behalf. ${ }^{128}$

125. 406 U.S. at 618 (Rehnquist, J., dissenting).

126. See, e.g., Chinton, supra note 66 , at $776-77$.

127. Faretta v. California, 422 U.S. 806,819 n.15 (1975).

128. The arguinent that the state inay not preclude a defendant from reserving his decision as to whether to take the witness stand in his own defense inust be distinguished from the arguinent set forth in the next section, viz, that the state inay not preclude a defendant from putting his own testimony into evidence at the time during the trial when he beheves it will be inost effective. Ultimately, both arguments derive froin the constitutional right of a defendant to testify on his own behalf, but the arguments are conceptually different. The first argument assumes that the right to testify is so strong that a defendant should be entitled to postpone until the end of trial the decision whether to exercise the right. However, as we see in this section, the argument must be rejected. The state can use the threat of preclusion to induce a defendant to inake up his mind at the outset of his case as to whether to take the witness stand, provided that the state's purpose is to induce the defendant to testify, if at all, at the time when his testimony will be most reliable. Nonetheless, it does not follow that the state's interest is also sufficient to override a defendant's interest in putting his testimony into evidence at the time when he thinks it will be most effective. On the contrary, as we shall see in the next section, the right of a defendant to control the timing and sequence of evidence in his favor is stronger than his right to reserve decision as to whether to testify at all, and is sufficient to override the state's interest in seeing that he testify, if at all, as the first witness for the defense.

In sum, it is ultimately correct to say that the Brooks statute was unconstitutional because it imposed an unconstitutional burden on the right of a defendant to testify as a witness for the defense. But it is important to identify the particular nature of the defendant's "right." It is not 


\section{A. Distinctions Between the Right to Testify and the Right to Remain Silent}

This argument is conceptually distimct from the argument based on the privilege agamst self-incrimination, and the validity of the one is mdependent of the validity of the other. To illustrate the distinction, assume that a jurisdiction decides to amend its constitution by repealing the privilege against self-incrimination. It follows that while a defendant in this hypothetical jurisdiction has a constitutional right to testify on his own behalf, he no longer has a constitutional right not to testify, and cannot complain on fifth amendment grounds about being compelled to take the witness stand over his objection. Within the context of such a constitution, the legislature then adopts the Tennessee statute at issue in Brooks, requiring a defendant to testify, if at all, as the first witness for the defense. Under those circumstances, the Tennessee statute could hardly be said to violate the privilege against selfincrimination, because, by hypothesis, the privilege has been abolished within the jurisdiction. Yet by precluding a defendant from taking the witness stand after other witnesses had testified for the defense, the statute might still abridge his separate and independent right to testify in his own behalf.

Now it might be argued that while the right to testify is conceptually distinct from the right to remain silent, the one is essentially the converse of the other and, therefore, the Court's "timing" ${ }^{29}$ rationale in Williams should work equally well for both. After all, so the argument goes, the defendant in Brooks was not denied the right to take the witness stand any more than the defendant in Williams was denied the right to remain silent. Each was permitted to assert his respective constitutional privilege, provided that he do so in a timely fashion. Thus, the defendant in Brooks was perfectly free to decide to testify on his own behalf, provided that he make his decision by the close of the state's case. In that respect, the Tennessee statute accorded a defendant complete autonomy between exercising his right to testify on the one hand or his converse right to remain silent on the other. Accordingly, since the statute did not violate the defendant's right to remain silent by requiring that he decide at the close of the state's case whether to assert the right, ${ }^{130}$ the statute should not be deemed to violate his right to take the witness stand in requiring that he also make the converse decison at the same time.

The trouble with this analogy to the right to remain silent is that it

the right to reserve a decision as to whether to testify at all; it is the right of a defendant to present witnesses (including himself) in the sequeuce in which their testimony will be most effeetive.

129. 399 U.S. at 85 .

130. See text accoinpanying notes $18-91$ supra. 
rests on one of two implicit assumptions. Either it assumes that the timing of a defendant's decision imposes no burden whatsoever on his respective constitutional interests; or, if timing does impose a burden, it assumes that the measure of the burden is the same for both the right to remain silent and the right to testify. Neither assumption is self-evident. As for the timing of the decision, it should be clear by now that a defendant is not in exactly the same position at different times before and during trial. The longer a defendant can delay a strategic decision, the more information he will have and the more knowledgeable his decision will be. The dissenters in Williams made that perfectly obvious. And even if they had not, it was implicit in the recognition by the majority in Williams that a defendant 1might decide to disclose his alibi before trial, and later, having seen and heard the state's case agamst him, decide not to rely on the defense at trial. ${ }^{131}$ Indeed, the majority explicitly stopped short of statimg that the pressures on a defendant at the two different times were identical and, mstead, admitted that at most the pressures were "similar." 132 Thus, in upholding the notice-ofalibi statute in Williams, the Court did not hold that the timing of the defendant's decision was wholly inconsequential, but rather that the consequences were not sufficiently grievous to violate his right to remain silent.

Nor can it be assumed that because the timing of the defendant's decision in Brooks was compatible with his right to remain silent, it must also be coinpatible with his right to testify in his own defense. The Court has never suggested that the measure of the two constitutional interests is the same. On the contrary, while the Court recognizes that a defendant has a constitutional mterest in not being compelled to become a witness agaimst himself, the Court has been willing to impose some burdens on the exercise of the privilege. ${ }^{133}$ Yet, with respect to the defendant's constitutional interest in being able to present evidence in his defense, the Court takcs the position that "few rights are inore fundamental."134 Sigmificantly, while the Burger Court has consistently rejected claims arismg under the privilege agamst selfincrimination, ${ }^{135}$ it has uniformly upheld claims arising under the de-

131. 399 U.S. at 84.

132. Id.

133. See e.g., Lakeside v. Oregon, 435 U.S. 333 (1978); Baxter v. Palmigiano, 425 U.S. 308, 316-20 (1976); Gamer v. United States, 424 U.S. 648, 664-65 (1976); California v. Byers, 402 U.S. 424 (1971); McGautha v. California, 402 U.S. 183, 213-17 (1971); Harris v. New York, 401 U.S. 222 (1971).

134. Chambers v. Mississippi, 410 U.S. 284, 302 (1973).

135. This tendency on the part of the Burger Court to rejeet claims under the privilege against self-imcrimination is im marked contrast to the Court's behavior during the previous decade. During the later years of the Warren Court, the Court consistently upheld claims under the privilege and, thereby, greatly enlarged its scope. See, e.g., Leary v. United States, 395 U.S. 6 (1969); Orozco v. Texas, 394 U.S. 324 (1969); Simmons v. United States, 390 U.S. 377 (1968); Sanitation 
fendant's right to present evidence in his defense. ${ }^{136}$ The upshot of all this is that regardless of its effect on the privilege against self-incrimination, the statute in Brooks inust be independently analyzed for the validity of its effect on the defendant's right to testify.

\section{B. Justifications for Precluding a Defendant from Testifying}

One can begin the analysis by identifying the state's purpose in resorting to the preclusion sanction, and then evaluating the effect of the sanction in light of those purposes. The preclusion sanction served two purposes in Brooks: (1) it was designed to exclude potentially unreliable evidence by prohibiting the defendant from giving testimony that he inay have falsely tailored to conform to the prior testimony of other defense witnesses and (2) it was designed to induce the defendant to present his own testimony in its most probative form by threatening to prevent him from taking the witness stand unless he testified at the time when his testimony would be most reliable. If either of these two statutory purposes suffices to override a defendant's constitutional interest in

Men v. Sanitation Comm'r, 392 U.S. 280 (1968); Gardner v. Broderick, 392 U.S. 273 (1968); Greenwald v. Wisconsin, 390 U.S. 519 (1968); Haynes v. United States, 390 U.S. 85 (1968); Grosso v. United States, 390 U.S. 63 (1968); Marchetti v. United States, 390 U.S. 39 (1968); In re Gault, 387 U.S. 1 (1967); Clewis v. Texas, 386 U.S. 707 (1967); Spevack v. Klein, 385 U.S. 511 (1967); Garrity v. New Jersey, 385 U.S. 493 (1967); Davis v. North Carolina, 384 U.S. 737 (1966); Miranda v. Arizona, 384 U.S. 436 (1966); Stevens v. Marks, 383 U.S. 234 (1966); Albertson v. Subversive Activities Control Board, 382 U.S. 70 (1965); Griffin v. California, 380 U.S. 609 (1965); Murphy v. Waterfront Comm'n, 378 U.S. 52 (1964); Malloy v. Hogan, 378 U.S. 1 (1964). But see Gilbert v. California, 388 U.S. 263 (1967); United States v. Wade, 388 U.S. 218 (1967); Schmerber v. California, 384 U.S. 757 (1966).

The Burger Court, on the other hand, has almost unifornally rejected clains under the privilege. See, e.g., Lakeside v. Oregon, 435 U.S. 333 (1978); United States v. Washington, 431 U.S. 181 (1977); United States v. Wong, 431 U.S. 174 (1977); Oregon v. Mathiason, 429 U.S. 492 (1977); Andresen v. Maryland, 427 U.S. 463 (1976); Mandujano v. United States, 425 U.S. 564 (1976); Fisher v. United States, 425 U.S. 391 (1976); Beckwith v. United States, 425 U.S. 341 (1976); Baxter v. Palınigiano, 425 U.S. 308 (1976); Garner v. United States, 424 U.S. 648 (1976); Michigan v. Mosely, 423 U.S. 96 (1975); United States v. Nobles, 422 U.S. 225 (1975); Oregon v. Hass, 420 U.S. 714 (1975); Michigan v. Tucker, 417 U.S. 433 (1974); Bellis v. United States, 417 U.S. 85 (1974); United States v. Dionisio, 410 U.S. 1 (1973); Couch v. United States, 409 U.S. 322 (1973); Kastigar v. United States, 406 U.S. 441 (1972); California v. Byers, 402 U.S. 424 (1971); McGautha v, Cahfornia, 402 U.S. 183 (1971); Harris v. New York, 401 U.S. 222 (1971); Williams v. Florida, 399 U.S. 78 (1970); United States v. Kordell, 397 U.S. 1 (1970); Minor v. United States, 396 U.S. 87 (1969); United States v. Knox, 396 U.S. 77 (1969). But see Lefkowitz v. Cunningham, 431 U.S. 801 (1977); Maness v. Meyers, 419 U.S. 449 (1975); Lefkowitz v. Turley, 414 U.S. 70 (1973).

Another index of this change in direction is the relative position of Justices Byron White and Potter Stewart on the one hand and Justice William Brennan on the other. During the Warren Court years the forner were almost always in dissent in cases arising under the privilege; today they are almost always with the inajority. $C f$. Lakeside v. Oregon, 435 U.S. 333, 342 (1978) (Stevens, J., dissenting). The opposite is true with respect to Justice Brennan: He was always with the inajority during the Warren Court years and now finds himself regularly in dissent in cases construing the privilege.

136. See generally Clinton, supra note 66 , at 756-92, 857-58. 
testifying as a witness for the defense, it follows that the preclusion sanction in Brooks was valid and that it did not violate the defendant's constitutional right to testify on his own behalf.

\section{To Exclude Unreliable Evidence}

The first of these two purposes-the exclusionary purpose-is not by itself sufficient to justify its burden on the defendant's right to testify on his own behalf. An analogy can be drawn here between the defendant's constitutional right to take the witness stand himself and his constituitional right to call other witnesses in his defense. The Supreme Court has held that preclusion may not be used to prevent a defendant froin calling potentially untrustworthy witnesses simply because their testimony carries some indicia of unreliability. The controlling case is Washington $v$. Texas. ${ }^{137}$ The defendant in Washington cliallenged a Texas statute that precluded him from calling his coindicted accomplice as a witness for the defense, arguing that the statute violated the defendant's sixth amendment right to present "witnesses in lis favor." 138 The state defended the statute on the ground that it was designed to exclude potentially unreliable evidence, noting that "if two persons charged with the same offense were allowed to testify on belualf of each other, 'each would try to swear the other out of the cliarge." "139 The Supreme Court did not deny that the accomplice's testimony contained elements of untrustworthiness; nor did it deny that the state had a legitimate interest in the accuracy of criminal proceedimgs, or that exclusion was reasonably designed to further that interest. Ratler, the Court held that the remedy of exclusion, thougl reasonable, was excessive given the less drastic alternative of "leaving the credit and weight of such testimony to . . . the jury ...":

This rule [disqualifying accomplices from testifymg in favor of one another] . . . rested on the unstated premises that the right to present witnesses was subordimate to the court's interest in preventimg perjury, and that erroneous decisions were best avoided by preventimg the jury from hearing any testimony that might be perjured, even if it were the only testimony available on a crucial issue. . . . [We believe] that "the truth is more likely to be arrived at by hearing the testimiony of all persons of coinpetent understanding who may seem to have knowledge of the facts involved in a case, leaving the credit and weight of such testimony to be determined by the jury or by the court . . . ."140

The same reasoning also applies to Brooks. Like the statute in Washington, the Brooks statute was rationally designed to further the

137. 388 U.S. 14 (1967).

138. "In all criminal prosecutions, the accused shall enjoy the right . . . to have compulsory process for obtaining witnesses in his favor." U.S. CoNST. amend. VI.

139. 388 U.S. at 21 .

140. Id. at 21-22 (citations omitted). 
state's legitimate interest in the accuracy of criminal proceedings by excluding testimony that presented the risk of having been falsely tailored to conform to prior evidence at trial. Both statutes rested on the premise that the right to present evidence was "subordinate"141 to the "interest in preventing perjury,"142 and "that erroneous decisions were best avoided by preventing the jury from hearmg any testmiony that might be perjured."143 Yet in both cases the state could have furthered its interests by the less drastic alternative of leaving the weight and credibility of the questionable testimony to the jury. Consequently, insofar as the preclusion sanction in Brooks was solely designed to exclude untrnstworthy testimony, it was presuinably invahd for the same reason as the statute in Washington, namely that it "arbitrarily denied [the defendant] the right to put on the stand a witness who was physically and mentally capable of testifying to events that he had personally observed, and whose testimony would have been relevant and material to the defense." 144

\section{To Encourage Trustworthy Testimony}

Ultimately, therefore, the validity of the preclusion sanction in Brooks depends on the sufficiency of the second of the two supporting rationales set forth above. This second rationale for the preclusion sanction is not only stronger, it is also inore closely tied to the actual operation of the statute in Brooks because the statute's essential feature was to regulate the timing of the defendant's testimony, rather than to exclude it altogether. Unlike the Washington statute, the Brooks statute was not designed solely to exclude testimony that might have been falsely tailored to conform to prior evidence. If that had been its sole purpose, it would have applied to exclude such testimony without exception and without regard to the circumstances or to the defendant's reasons for failing to coinply with the rule. ${ }^{145}$ Rather, the statute was

141. 388 U.S. at 21.

142. Id

143. Id.

144. 388 U.S. at 23. Westen, supra note 80, at 118-19. See also, State v. Jones, 354 So. 2 d 530, 532 (La. 1978):

Although our jurisprudence allowing trial judges to enforce sequestration [rules] . . . by excluding testimony of disobedient witnesses does reflect a legitinate state interest in preventing testimonial influence, that interest is not sufficient to override the defendant's rights to have compulsory process and to present a defense under either the federal or the state constitution. This is not to imply that there may be no risk of a witness coloring his testimony to conforin to what has gone before. But our adversary system reposes judgment of the credibility of all witnesses in the jury. Excluding the witness' testimony . . . is not a constitutionally permissible means of insuring reliable testimony.

145. The Tennessee statute was not a mandatory rule of exclusion, but rather a flexible rule to be applied, or not, depending on the circumstances. See 406 U.S. at $611, n .7$. This is also true of discovery statutes which, in providing for preclusion as a sanction, almost always give the judge discretion in invoking the sanction. See Note, The Preclusion Sanction, supra note 41, at 1343 n.14. But see Kan. Stat. AnN. \& 22-3218(4) (Supp. 1971) (preclusion is the mandatory sanction 
designed to encourage defendants to behave in a certain way- specifically, to induce them to present their testimony at the time during trial when it would be most trustworthy. Indeed, that is what it means to say that preclusion was designed to operate as a "sanction." Preclusion was the penalty that followed upon the defendant's failure to comply with a state-created duty to present his testimony, if at all, $m$ its most probative form. As with all sanctions, the purpose of the preclusion sanction was to deter undesired behavior-and hence to encourage desired behavior-on the part of the defendant.

This is not the place for a comprehensive analysis of the preclusion sanction. ${ }^{146}$ It is sufficient to say that the Supreme Court has sustained the use of the preclusion sanction in circumstances analogous to Brooks. The controlling case is United States $v$. Nobles. ${ }^{147}$ The defendant in Nobles sought to impeach a prosecution witness by calling a defense investigator to testify to statements previously obtained from the prosecution witness by the investigator that were inconsistent with the witness' in-court testimony. Before allowing the defense investigator to take the witness stand, however, the trial court ordered the defendant to disclose a copy of the investigator's written report of his interview with the witness. As a consequence of his refusal to disclose the report, the defendant was precluded from calling the mvestigator as a witness and was convicted. He thereafter challenged his conviction on the ground that even if he had a lawful duty to disclose his investigator's report, the duty could not constitutionally be enforced by the sanction of precluding him from calling a witness " $\mathrm{m}$ his favor." 148

The Supreme Court rejected the defendant's sixth amendment argument, holding that "the court's preclusion sanction was an entirely proper inethod of assuring compliance with its order." 149 The Court distmguished Washington v. Texas on two grounds: first, that the preclusion sanction in Nobles did not disqualify the defendant from ever calling the investigator as a witness "in his favor," but merely regulated the conditions under which the witness could be called; and second, that the purpose of the sanction was to induce the defendant to make disclosures that would enhance the reliability of the witness' testimony:

for failure to coinply with a notice-of-alibi statute). The purpose of giving the judge discretion is to permit him to tailor the sanction to the circumstances of the violation, including the degree to which the defendant had control over the nondisclosure and the willfulness or bad faith of his nondisclosure. See generally Note, The Emerging Deterrence Orientation in the Imposition of Discovery Sanctions, 91 HaRv. L. REV. 1033 (1978).

146. The most useful general treatments of the issue are Clinton, supra note 66, at 830-41; Note, The Preclusion Sanction, supra note 41; and Note, The Emerging Deterrence Orientation in the Imposition of Discovery Sanctions, supra note 145.

147. 422 U.S. 225 (1975).

148. Brief for the Respondent at 48-57.

149. 422 U.S. at 241. 
The sixth amendment does not confer the right to present testimony free from the legitimate demands of the adversarial system; one cannot invoke the sixth amendment as a justification for presenting what might have been a half-truth. Deciding, as we do, that it was within the court's discretion to assure that the jury would hear the full testimony of the investigator rather than a truncated portion favorable to [the defendant], we think it would be articifial imdeed to deprive the court of the power to effectuate the judgment. ${ }^{150}$

As with all cases of first impression, Nobles can be read either broadly or narrowly. Any definitive statement of the case will have to await its future application in related factual settings. Meanwhile, it is appropriate to assume from the Court's hesitancy in this area ${ }^{151}$ that the Court's approval of the preclusion sanction should be construed narrowly. On that assumption, I suggest that Nobles be taken to stand for the following proposition:

A state may preclude a defendant from calling a witness to the witness stand, mcludimg the defendant himself, ${ }^{152}$ if the defendant (a) wilfully violates a known duty of disclosure ${ }^{153}$ (b) that is otherwise lawfully vahd ${ }^{154}$ and (c) that is designed to enhance the rehability of the witness' evidence, ${ }^{155}$ provided that (d) alternative sanctions are not clearly

150. Id.

151. Before finally reaching the issue in Nobles, the Court twice went out of its way to refrain from passing on the constitutionality of the preclusion sanction. See Williams v. Florida, 399 U.S. 78,83 n.14 (1970):

We emphasize that this case does not involve the question of the vahidity of the threatened sanction, had petitioner chosen not to comply with the notice-of-alibi rule. Whether and to what extent a State can enforce discovery rules against a defendant who fails to comply, by excluding relevant, probative evidence is a question raising Sixth Amendinent issues which we have no occasion to explore.

See also Wardius v. Oregon, 412 U.S. 470,472 n.4 (1973) ("we express no view as to whether a vahd [notice-of-ahibi] rule could be . . . enforced [by preventing a defendant from calling alibi witnesses at trial]"). This hesitancy suggests doubt on the Court's part regarding the constitutionality of applying the preclusion sanction to prevent a defendant from offering evidence on his behalf, and, thus, suggests that the Court's limited intrusion upon that right in Nobles ought to be construed narrowly.

152. There is no constitutional difference in scope between the right of a defendant to call himself as the witness and his right to call third persons as witnesses in his defense. See note 93 supra.

153. The Supreme Court has suggested that even in a civil case it may be unconstitutional to deny a party a hearing on the merits of his claim because of his failure to comply with a vahd discovery order, if he made a "good-faith" effort to comply. Societe Internationale v. Rogers, 357 U.S. 197, 210 (1958). Cf. National Hockey League v. Metropolitan Hockey Club, 427 U.S. 639, 643 (1976) (the preclusion sanction is appropriate under Federal Civil Procedure Rule 37 where the party being sanctioned acted in "flagrant bad faith").

154. A defendant should always be able to challenge the imposition of the preclusion sanction if he can show that the sanction was designed to enforce a duty of disclosure that is itself invalid. See, e.g., Wardius v. Oregon, 412 U.S. 470 (1973) (defendant cannot be precluded from calling alibi witnesses in his defense because of his failure to give pretrial notice of their identity, where the duty to make pretrial disclosure was itself invahid for lack of reciprocity).

155. The Court in Nobles emphasized that the preclnsion sanction was designed to enforce a duty of disclosure that was itself designed to avoid "half-truth[s]." 422 U.S. at 241 . If this is a necessary himitation, it means that the preclusion sanction could not be used to enforce a duty of the defendant's that has nothing to do with enhancing the reliability of the factfinding process, 
superior, ${ }^{156}$ (e) the scope of preclusion is limited to the particular items of evidence that are less reliable because of the defendant's nondisclosure, ${ }^{157}$ and (f) application of the sanction is reasonably likely to be effective in enforcing the duty of disclosure. ${ }^{158}$

The statute in Brooks satisified the foregoing test. The defendant was fully aware of his duty to testify (if at all) as the first witness for the defense, and his failure to comply with the rule was clearly intentional. ${ }^{159}$ The statute prescribed a lawful duty of disclosure in that the

such as, say, a duty to pay a filing fee. Cf. Hammon Packing Co. v. Arkansas, 212 U.S. 322, 350. 351 (1909) (the preclusion sanction may not be used in a civil case "as a mere punishment" for failure to comply with a court order).

156. Some commentators have suggested that a court may not resort to the preclusion sanction unless it possesses "more than marginal" advantages over the alternative sanctions that may otherwise be available. Note, The Preclusion Sanction, supra note 41, at 1361. This, in turn, has led at least one commentator to conclude that the preclusion sanction either "can [n]ever be constitutionally applied for failure to [make disclosure]," or only be applied "im the unusual case where other means of effectuating the state's interests are practically unavailable." Chinton, supra note 66 , at 833,839 .

This standard appears to be too strict. In Nobles, for example, the Court impliedly rejected the defendant's argument that the preclusion sanction could not constitutionally be applied, unless the trial court first concluded that the less drastic alternative sanctions-e.g., contempt, a continuance, a comment on the defendant's failure to make the disclosure-were "imadequate." Brief for the Respondent at 57-59. The same thing was true in Illinois v. Allen, 397 U.S. 337 (1970). The defendant in Allen, having been removed from the courtroom as a sanction for violating a lawful order to refrain from disruptive behavior, argued that the sanction of removal was excessive and that the trial court should not have resorted to a removal before first exhausting the less drastic alternative sanctions of conteinpt, civil contempt, and binding and gagging him. The Court rejected the standard, holding that "no one formula for inaintainimg the appropriate courtroom atmosphere will be best in all situations" and that the trial judge should have "discretion" to select the sanction that he considers appropriate under "the circunstances of each case." 397 U.S. at 343.

In sum, it is unnecessary to show that the preclusion sanction is the only way that a court can effectively enforce a duty of disclosure. Rather it is sufficient to show that the sanction is "appropriate" under the "circumstances." 397 U.S. at 345. The sanction in Brooks meets that test. To be sure, there may have been other combimations of sanctions that might have worked as well in Brooks, but the preclusion sanetion was the only one that tailored its deterrent effect to the scope of the defendant's violation and, simultaneously, repaired the imjury to the factfinding process that would have resulted from the defendant's nondisclosure. And that should be sufficient to justify selecting it over alternative sanctions or combinations of sanctions.

157. As David Louisell has said, "it is subınitted . . that . . . the guiding principle [of sanctions for noncompliance with duties of disclosure] ought to be to apply no sanction harsher than is reasonably necessary to achieve the purpose of compliance." D. LouISELL \& B. WALLY, supra note 94, § 12.8, at 738. Cf. Hammond Packing Co. v. Arkansas, 212 U.S. 322, 350-51 (1909) (it violates due process in a civil case to apply a preclusion sanction under circumstances where its effect goes beyond curing probative deficiencies that would have resulted from noncompliance with the court ordered duty).

158. The Supreme Court has said that even in a civil case a "serious constitutional question" would be raised by the use of the preclusion sanction against a party because of his failure to comply with a discovery order, if his failure was due to "mability, and not to willfulness, bad faith, or any fault of [his]." Societe Internationale v. Rogers, 357 U.S. 197, 212 (1958).

159. That the defendant in Brooks was fully aware of his testimonial duty can be inferred from his motion in advance to dispense with his obligation to testify as the first witness for the defense. Moreover, the defendant's violation of the rule was unexcused in the sense that it followed upon the trial judge's advance ruling that the statute applied to the defendant in the specific circumstances of his case. 
disclosure served a rational procedural purpose and did not violate either the privilege against self-incrimination or the right to counsel. ${ }^{160}$ The purpose of the disclosure was to enhance the reliability of the factfinding process by assuring that the defendant's testimony be given prior to the point at which it could be falsely "tailored" to conform to the testimony of other defense witnesses. The scope of the preclusion in Brooks was limited to the very testimony-the defendant's own evidence-that the duty of disclosure was designed to render rehable.

Finally, the sanction of preclusion was reasonably likely to be effective in inducing the defendant to make his disclosure at the close of the state's case because the threat of preclusion was brought to bear on the defendant at a time when he was fully aware of his duty of disclosure and of the consequences of preclusion, and was still able to take action to avoid the sanction. To be sure, the degree to which the preclusion sanction is effective in enforcing a duty of disclosure depends on the degree to which the defendant, at the time he is called upon to make the disclosure, can accurately assess the potential value of the particular itein of evidence. Two factors inay prevent a defendant from making this assessment. First, because of the lack of pretrial discovery of the prosecution's case, a defendant may be unaware of the strength and nature of the state's case against him; and second, because of unforeseen (or unforeseeable) contingencies, a defendant may be unable to reasonably anticipate what his own witnesses will say at trial. In eitler event, he inay underestimate the eventual "cost" to his case of being precluded froin presenting certain items of exculpatory testimony. To the extent that the defendant reasonably underestimates this cost, preclusion loses its effectiveness as a sanction and, therefore, loses

160. To be sure, it is the conclusion of this Article that by imposing a duty on the defendant to testify as the first witness for the defense, the Tennessee statute violated the defendant's constitutional right to control the timing and sequence of evidence in his defense. See text accompanying notes 163-88 infra. If that conclusion is correct, it ineans that the statutory duty was illegal and that the preclusion sanction could not constitutionally be used to enforce it. To that extent the use of the preclusion sanction violated the defendant's constitutional right to testify in his own defense. But this latter violation is a secondary (and dependent) consequence of the fact that the statutory duty of disclosure was itself nnconstitutional. Thus, the primary defect of the Tennessee statute was not that it resorted to the preclusion sanction to enforce a testimonial duty, but that it used the preclusion sanction to enforce a testimonial duty that was itself unconstitutional on independent grounds.

This saine relationship between primary and secondary violations can be illustrated by the argument that the Brooks statute violated the defendant's right to counsel. Once it is concluded that the Teimessee statute imposed an unconstitutional duty on the defendant to testify as the first witness for the defense, then it follows a fortiori that the statute also violated the defendant's constitutional right to be assisted by counsel with respect to all the things he was constitutionally entitled to do at trial. To that extent, the Termessee statute can also be said to have violated the defendant's right to counsel. But again, the right to counsel argument has no independent force of its own; it is subordinate and entirely dependent on the defendant's being able to establish that there was a primary violation of soine other and independent constitutional guarantee. See text accompanying notes $116-25$ supra. 
its constitutional justification as a burden on the defendant's right to present evidence in his defense. ${ }^{161}$

Brooks contained none of these defects. The defendant had complete knowledge of the state's case-in-chief at the time of the required disclosure, because he was not called upon to make his decision until after the close of the state's evidence. To be sure, the defendant could not know for certain how his witnesses would testify until they actually did. But there is no reason to believe that he was surprised by the testimony. ${ }^{162}$ While he could not be absolutely certain at the close of the state's case about the precise nature of his witnesses' testimony, he was reasonably capable of making a realistic assessment about the potential value of his own testimony, which is all that should be constitutionally required for preclusion to operate as a rational sanction.

In suin, the sanction in Brooks satisfies the criteria for determining the constitutional validity of a preclusion sanction. Accordingly, just as the preclusion sanction in Nobles was held not to violate the defendant's sixth amendment right to call "witnesses in his favor," the sanction in Brooks should not be deemed to violate the defendant's constitutional right to call himself as a witness for the defense.

161. "Imposing harsh [preclusion] sanctions in the absence of an unexcused willful or negligent discovery failure not only would contravene Societe Internationale, but it would be irrational, since innocent failures seldoin can be deterred." Note, The Emerging Deterrence Orientation in the Imposition of Discovery Sanctions, 91 HaRv. L. REv. 1033, 1050 (1978). In People v. Rayford, 43 III. App. 3d 283, 356 N.E.2d 1274 (1976), the defendant was precluded from calling an expert witness to the witness stand because the defendant had failed to comply with a lawful rule rcquiring him to disclose the identity of his witnesses to the prosecution in advance of trial. The defendant argued that it was unconstitutional to apply the preclusion sanction in his case, because he became aware of the value of the witness' testimony only after the trial had begun. The court of appeals agreed, holding that it was "excessive," and therefore unconstitutional, to apply the preclusion sanction against a defendant whose failure to make pretrial disclosure was reasonable at the time of his decision. See also Braswell v. Wainwright, 463 F.2d 1148 (5th Cir. 1972) (use of the preclusion sanction is excessive and, thcrefore, unconstitutional if the defendant's failure to comply with the underlying rule was reasonable and understandable under the circumstances); State v. Jones, 354 So. $2 \mathrm{~d} 530$ (La. 1978) (same). Thus, it can be inferred that under other circumstances the Tennessee statute at issue in Brooks might be unconstitutional as applicd. If the foreseeable conditions underlying a defendant's original decision not to testify changed-if, for example, a key defense witness died or the defense had been forced to call a hostile witness whose testimony was unpredictable-it might be unconstitutional to preclude the defendant from testifying after he had put on another witness.

162. On the contrary, the defendant in Brooks requested relief from the preclusion sanction before any of his own witnesses had testified for the defense, which suggests that he was already aware of the contingencies that might affect the eventual value of his own evidence. Moreover, having decided not to testify as the first witness for the defense, he did not thereafter renew his request to testify out of order, which again suggests that he was not surprised by anything his witnesses actually said. If he had been, he might have had an additional complaimt agamst the statute as applied. See note 161 supra. 


\section{V}

\section{The Right to Control the Order of Proof}

Brooks cannot be explained by any of the three principles discussed above. It follows, therefore, that if the case was correctly decided - as the Court continues to take it to be ${ }^{163}$ - then it must be based on still a fourth and yet unidentified principle of constitutional procedure. In my judgment, there is only one possibility: the Tennessee statute was unconstitutional because it arbitrarily interfered with the defendant's interest in maximizing the probative effect of his evidence by structuring the timing and sequence of its presentation. If this construction is correct, its inplications are significant. It nieans that Brooks was a constitutional case of first impression. It nieans that Brooks constitutionalizes an aspect of the criminal trial that until now has gone unregulated. It ineans that defendants now have a constitutional interest in being able to control order-of-proof with respect to evidence in their defense.

The Tennessee statute, it will be recalled, did more than require a defendant to disclose his intended testinnony at the outset of his case; it required that he also place such testnnony into evidence at that particular time or have it barred froni admission. In other words, the statute did more than compel disclosure at an earher time than the defendant might have chosen; it also interfered with the defendant's order-ofproof. It was this additional feature that distinguished the statute in Brooks from the statute in Williams. The Tennessee statute prevented the defendant im Brooks from structuring his evidence in the sequence that would most effcctively persuade the jury of the truth of his defense.

The real problen with the Tennessee statute, therefore, was not that it abridged the defendant's right to remain silent, or that it denied him assistance of counsel, or that it prevented him from testifying im his own defense; rather, the statute was invalid because it abridged his right to testify at the tinne he judged his testimony wonld be inost effective. This is presuinably what the dissenters in Brooks meant when they said that the real defect in the statute, if any, was that it violated the defendant's "right . . . to decide at what point during the presentation of his case to take the stand." 164 This is probably what the majority, too, had im mind in holding that the statute violated the right of "the accused and his counsel" to decide "when in the course of presenting his defense, the accused shonld take the stand." 165 Indeed, the niajority's only mistake was to attribute the defendant's imterest in the

163. Lakeside v. Oregon, 435 U.S. 333, 339 n.9 (1978); Geders v. New York, 425 U.S. 80, 91 (1976); Herring v. New York, 422 U.S. 853, 857 (1975).

164. 406 U.S. at 618 (Rehnquist, J., dissenting).

165. 406 U.S. at 613 . 
"timing"166 of his testimony to his right to counsel. For if it is true that a defendant has a constitutional interest in being able to control the timing of his testimony, it is not because his lawyer might want to call him later in the trial, but because "the defendant-whether advised by counsel or otherwise-wishes to determine at what point during the presentation of his case he desires to take the stand."167

If this interpretation of Brooks is correct, it follows that the Court implicitly recognized that a defendant has a constitutional interest in controlling the timing and sequence of evidence in his defense. ${ }^{168}$ This recognition will come as no surprise to practitioners and students of the trial process, because they have long understood that the "order for sequencing the presentation of [evidence]"169 results in "a significant difference in the [factfinder's] final judgments." 170 There are at least two reasons why the effective presentation of a case depends on the order in which witnesses are called: first, it "aids the jury both im understanding and remembermg the testimony" 171 for a defendant to present his evidence in the form of a "logical progression"; 172 second, a defendant has an interest in deciding when to call his strong witnesses and when to call his weak witnesses, because "the timing of evidence may inaterially affect its influence upon the jury."173 The Tennessee statute violated the defendant's control in each respect, because it required him to take the witness stand, if at all, as the very first witness for the defense.

166. Williams v. Florida, 399 U.S. 78, 85 (1970).

167. 406 U.S. at 618 (Rehnquist, J., dissenting).

168. See Amsterdam, supra note 4, at 404 ("The implications of Brooks are staggering. To start with, it suggests real federal constitutional limitation on the ordinary order of proof which trial judges can insist on . . . .); Dix, Waiver in Criminal Procedure: A Brief For More Careful Analysis, 55 TEXAS L. REv. 193, 240 (1977) ("[Brooks] is difficult to defend on any grounds other than a defendant's right to make maximum tactical advantage of his own testiunony"). Cf. F. Bailey \& H. Rothblatt, Successful Techniques for Criminal Trials 352 (1971) (the defendant has a constitutional right "to develop the evidence as [he] see[s] fit").

To be sure, it does not follow automatically that because a defendant has a constitutional right under Brooks to control the timing and sequence of his own testinony, he must also have a right to control the timing and sequence of the testimony of his other witnesses. Nonetheless, on the assumption that the right of a defendant to call third persons as witnesses in his defense is at least as strong as, if not stronger than, his right to call himself as a witness for the defense, it is reasonable to conclude that whatever interest he has in controlling the presentation of his own testimony applies equally as well to the presentation of theirs. See note 80 supra. See also Wright v. Estelle, 572 F.2d 1071, 1076 (5th Cir. 1978).

169. J. Thibaut \& L. Walker, Procedural Justice: A Psychological analysis 54 (1975).

170. Id. at 45. See also F. Busch, Trial Procedure Materials 159 (1961) ("The skilled advocate, desirous of making the inost effective presentation of his case, appreciates the importance of the order in which his testimony and written evidence are placed before the jury."); Walker, Thibaut \& Andreoli, Order of Presentation at Trial, 82 YALE L.J. 216 (1972).

171. R. Keeton, Trial Tactics and Methods 20 (1954).

172. Id.

173. Id. 
Indeed, with respect to order-of-proof, the Tennessee statute was particularly burdensome, because the defendant himself is often the key witness in the case and, in the view of most practitioners, there are "advantages [in] using the key witness late in the order of witnesses": 174

[M]ost practitioners normally save their strongest, most convimcing evidence for last. The usual justification for this strategy is that it is the most dramatic way to present one's case and that the jury or fact-finder will remember the strongest evidence inost vividly. One trial specialist suggests, for example, that the order of witnesses be arranged to "lead up to a climax ...."175

The importance of this strategy has now been confirmed by psychological testing. In their classic study of the psychological effects of orderof-proof in the adversary process, Laurens Walker and John Thibaut have demonstrated that the "order of presentation"176 of evidence is a "powerful source of influence"177 on the factfinder, and that "when strong evidence is presented late in the argument (as in the climax order) it carries greater weight than when it is presented early . . . ."178

In conclusion, if the decision in Brooks was correct, it was because the Tennessee statute interfered with what the Court imphitly found to be the defendant's constitutional interest in being able to regulate the order of evidence in his defense. Indeed, Brooks was a particularly easy case, because the state of Tennessee could have fully achieved its

174. Id. at 24. See also J. THIBAUT \& L. WALKER, supra note 169 , at 45,51 .

175. Walker, Thibaut \& Andreoli, supra note 170, at 216. Teachers of oral advocacy contend that the same is true of speeches and closing arguments. See L. STRYKER, THE ART OF ADVoCACY 148 (1954): "A speech inust progress in order to move. It must press on from point to point. It must with each paragraph rise a little higher until at last, through an ever-ascending series of words and clauses, it mounts finally to the bright pinnacle of a climax." Accord 2 M. BELLI, MODERN TRIALS $\S 306$ (1954).

To be sure, some defendants inay prefer the anticlimax order either as a general practice or under the circumstances of a particular case. But that does not mean that a defendant who decidedly prefers the climax order in a particular case should not be able to achieve it. At most it means that the decision should be left to the defendant in eacli case to make for himself. See F. BAILEY \& H. RothBLATT, supra note 168 , at 352.

176. J. THIBAUT \& L. WALKER, supra note 169 , at 45 .

177. Id. at 54 .

178. Id. at 63. Professor Robert Lawson's research has led to the same conclusion:

With most courtrooln communications . . . an arrangement of a persuasive communication in a climax order should be more effective than an arrangement in an anti-climax order. This prediction is based upon an assumption that most courtroon audiences, whether consisting of judges or jurors, have sufficient interest in the subject natter of the litigation to guarantee a reasonably high level of attention during presentation of persuasive arguments. ... [This assumption is especially true of] criminal litigation ... .

Lawson, Experimental Research on the Organization of Persuasive Arguments: An Application to Courtroom Communications, 1970 LAW \& Soc. ORD. 579, 607-08 (1970).

Psychologists describe the tendency of persons to remember best the testimony they have heard most recently as the "recency" effect. See A. Luchins, Primacy-Recency in Impression Formation, in The Order of Presentation in Persuasion (C. Hovland ed. 1957). See also E. JoNes \& G. Goethals, ORDER EFFECTS IN IMPRESSION Formation: ATtribution CONTEXT AND THE NATURE OF THE ENTITY (1971). 
objectives without imposing any burden on the defendant's order of proof. The purpose of the statute, after all, was to prevent the defendant from falsifying his own testimony by tailoring it to fit the prior testimony of witnesses in his defense. Accordingly, the state could have protected itself agamst that danger by the use of ordinary discovery procedures. The state could have required the defendant to disclose the substance of his intended testimony to the prosecution either before trial, or out of the jury's hearing at trial before other witnesses testified for the defense, without, however, requiring that he also place his testinony into evidence at that time. A requirement of disclosure of this kind would not violate the defendant's privilege against self-incrimination because, as in Williams, it merely requires the defendant to disclose in advance what he otherwise intends to disclose at trial. Nor would it violate his right to regulate the sequence of evidence in his defense, because having once disclosed his intended testimony to the proseeution, he could then take the witness stand at trial at any time he wished. Yet the required disclosure would serve fully the state's interest in being able to identify the defendant's original and untainted version of events and to preserve it in a forn from which he could not later depart at trial without risking impeachment. ${ }^{179}$

In sum, the Tennessee statute was unconstitutional because in addition to requiring that the defendant disclose his testimony at the close of the state's case, it also required that he actually put his testimony into evidence at that time or be precluded from having it adinitted later and, to that extent, imposed an unnecessary burden on the defendant's "right . . . to decide at what point during the presentation of his case to take the stand." 180 To be sure, it is often said that "the order in which testimony shall be adnnitted is largely withm the discretion of the trial

179. To be sure, the Court in Williams explicitly reserved the question of whether a defendant, having given pretrial notice of an alibi defense, can be impeachcd at trial for prcsenting evidence tluat is inconsistent with his announced alibi. 399 U.S. at $84 \mathrm{n.15}$. Nonetheless, it is hard to believe that the Court would forbid sucl impeachment. For one thing, in the course of reserving the question in Williams, the Court went on to refer with apparent approval to Simos v. Burke, 41 Wis. 2d 129, 137, 163 N.W.2d 177, 181 (1968), in which the Wisconsin Supreme Court rejected the constitutional objection. 399 U.S. at 84-85 n.15. Furthermore, the Court has shown itself to be quite lostile to efforts by criminal defendants to avoid being inpeacled at trial on the basis of prior inconsistent statements. See, e.g., Oregon v. Haas, 420 U.S. 714 (1975) (an incriminating statement taken froin a defendant in violation of his right to counsel and, therefore, inadmissible against him as part of the state's case-m-chief may nonetheless be used to impeach lim for giving inconsistent testimony at trial); Harris v. New York, 401 U.S. 222 (1971) (an incriminating statement taken from a defendant in violation of Miranda and, therefore, madmissible as evidence against him for its truth may nonetheless be used to impeacl the dcfendant for taking the stand and giving inconsistent testimony at trial). $C$ f. United States v. Wong, 431 U.S. 174 (1977) (if a witness is put in an unconstitutional trilemma between perjury, contempt, or self-incrimmation, sucl that he unay not be prosecuted for remaining silent or for making incriminating statements, he may nonetheless be prosecuted if lie responds by committing perjury).

180. 406 U.S. at 618 (Rehnquist, J., dissenting). 
court." 181 Indeed, the Supreme Court has paid eloquent tribute to this "power" of trial judges to regulate order-of-proof:

A criminal trial does not unfold like a play with actors following a script; there is no scenario and can be none. The trial judge inust meet situations as they arise and to do this must have broad power to cope with the complexities and contingencies inherent in the adversary process. To this end, he may determine generally the order in which parties adduce proof. ${ }^{182}$

To say that a trial judge "generally" has discretion to determine orderof-proof, however, does not mean the discretion is unregulated. For example, trial judges are also said to have discretion over other matters of proof-over admitting cumulative testimony, over excluding irrelevant testimony, and over "the scope of examination of witnesses." 183 Yet each of these areas of discretion is subject to constitutional limitation. Thus, a trial judge may not use his power over cumulative testimony to bar a defendant from calling material witnesses in his defense; ${ }^{184}$ a judge inay not prevent a defendant from presenting probative evidence in his defense by defining it as "irrelevant"; ${ }^{185}$ nor may he limit the scope of cross-examination in a manner that violates the defendant's right of confrontation. ${ }^{186}$ The same is also true of order-ofproof. A trial judge may exercise "substantial control" 187 over orderof-proof but not if it interferes with the right of the defendant to present his evidence im the sequence in which it will be most persuasive. ${ }^{188}$

181. Thiede v. Utah Territory, 159 U.S. 510,519 (1895).

182. Geders v. United States, 425 U.S. 80, 86 (1976).

183. "Within limits, the judge . . may refuse to allow cumulative, repetitive, or irrelevant testimony, . . . and may control the scope of examination of witnesses." Id. at 86-87.

184. See Westen, Compulsory Process II, 74 Mich. L. Rev. 191, 213-26 (1975). See also Gordon v. United States, 344 U.S. 414, 420-23 (1953).

185. See Westen, Confrontation and Compulsory Process: A Unified Theory of Evidence for

Criminal Cases, 91 HARv. L. Rev. 567, 626 n.162 (1978). Westen, supra note 184, at 205-09.

186. See Smith v. Illinois, 390 U.S. 129 (1968).

187. Geders v. United States, 425 U.S. 80,87 (1976).

188. [Brooks] suggests real federal constitutional limitation on the ordinary order of proof which trial judges can insist on; that is, forcing defense counsel to put on witnesses out of turn because this will be a short witness and that will be a long witness, or my witness number one is not available today and the court wants to go on.

Amsterdam, supra note 4, at 404.

This Article has a limited purpose. It is an attempt to provide authority for the proposition that a defendant has an interest im being able to regulate the timing and sequence of evidence in his favor and that this interest has constitutional underpinnings. It nuakes no attempt, however, to identify the standard for weighing or balancing the constitutional interest against other conflicting interests of state. Thus, the Artiele leaves open the question whether the defendant's interest in controlling the order of proof may be outweighed by other procedural considerations and, if so, whether these countervailing considerations must possess a certain degree of intensity before they may be held to override the defendant's interest. Cf. People v. Monaghan, $40 \mathrm{Ill}$. App. 3d 322, 327,352 N.E.2d 295, 299 (1976) (a defendant can be constitutionally required to present his own testimony out of the order that he prefers if his testimony is necessary for laying a foundation for the testimony of other defense witnesses). 


\section{ConClusion}

The decision in Brooks is both disturbing and encouraging. The decision is disturbing because it cannot be rationally defended on either of the two alternative grounds upon which the Court relied. With respect to the privilege against self-incrimination, the Court ignored or overlooked the controlling case of Williams $v$. Florida, and in doing so, caused soine commentators to conclude that Williams had actually been overruled. ${ }^{189}$ With respect to the right to counsel, the Court disposed of the entire problein in a single cursory paragraph and, in doing so, adopted a view of the sixth amendment that it has since had to repudiate. ${ }^{190}$

The encouraging thing about Brooks is that although the Court failed to identify the actual defect im the Tennessee statute, it sensed that the statute worked to undermine the defendant's right to a fair trial and decided the case accordingly, and implicitly left it to the legal community to identify the proper underlymg rationale. This aspect of Brooks would have pleased David Louisell, because he placed great faith im the mutual alliance of judges and scholars im the "quest for greater rationality in the adjudicative process." 191 It was part of his instinctive optimism ${ }^{192}$ and basic "trust in reason." 193

I believe that Louisell would also have been pleased with the particular result im Brooks. The importance of Brooks is that it completes the constitutional circle on order-of-proof: it provides the long-awaited

189. See, e.g., Lapides, Cross-Currents in Prosecutorial Discovery: A Defense Counsel's Viewpoint, 7 U.S.F. L. REv. 217, 228 (1973); Nakell, supra note 37, at 516 n.382. Cf. Amsterdam, supra note 4, at 405 (implicitly recognizing that with respect to the privilege against self-incrinination, the result in Brooks was inconsistent with the prior rationale in Williams).

190. See Lakeside v. Oregon, 435 U.S. 333, 341 (1978) (right to counsel is the right to the assistance of a lawyer regarding the existing rules for trying criminal cases, not the right to formulate or cliange such rules).

191. Louisell, The Theory of Criminal Discovery and the Practice of Criminal Law, 14 VAND. L. REv. 921 (1961).

192. What better way to illustrate the force of this optimism than to quote an epigram that Louisell enjoyed quotimg:

$$
\begin{aligned}
& \text { A little lady sat } \\
& \text { lamenting by the shore, } \\
& \text { deeply grieved that } \\
& \text { she saw the sun no more. } \\
& \text { My lady, ease thy mind } \\
& \text { and conquer thy despair, } \\
& \text { the sun that here deelined } \\
& \text { will soon rise over there. }
\end{aligned}
$$

Louisell, Book Review, 35 TeXas L. Rev. 892, 897 (1957).

The only cloud on Louisell's optimism appeared during his later years when he began to worry about the capacity of law, as the repository of our moral life, to cope with scientific and teclinological change. See Louisell, Biology, Law and Reason: Man as Self-Creator, 16 AM. J. JURIS. 1 (1971).

193. Louisell, supra note 18, at 90 . What Louisell said of his friend Roger Traynor could equally well have been said of Louisell himself: "I think; therefore, I hope." Id. 
second half of what until now has been an incomplete formulation of the constitutional right of a defendant to regulate the sequence of evidence in his defense. By constitutionalizing the right of a defendant to control the internal order-of-proof regarding his case-in-chief, Brooks complements the existing sixth ainendment right of a defendant to control the gross order-of-proof as between the prosecution and himself.

In order to appreciate Brooks in its larger constitutional context, it is important to understand two things: (1) the relationship between "gross" and "imternal" orders-of-proof, and (2) the parallel relationship between a defendant's right of confrontation and his right of compulsory process. With respect to order-of-proof, "gross" 194 order refers to the overall sequence im which the two sides to the case-the prosecution and the defense-present their respective cases-in-chief; "internal"195 order refers to the individual sequence in which each side presents particular items of evidence within its own case-in-chief. With respect to the sixth amendment, the defendant's right of confrontation is the right to demand that the state produce and tender for cross-examination those witnesses who are then available and whose statements the prosecution introduces into evidence "against him." The defendant's right of compulsory process is the right to insist that the state produce and make available for direct examination any remaiming witnesses who are then available and whose testimony the defendant wishes to imtroduce imto evidence "m his favor." 196

The gross order-of-proof in American criminal procedure is dictated partly by tradition and partly by a constitutional compulsion. ${ }^{197}$ Thus, tradition provides that as between the two sides, the prosecution presents its case first and the defendant presents his case second. ${ }^{198}$ In addition, however, the sixth anendinent entitles a defendant to inter-

194. J. Thibaut \& L. WALKER, supra note 169 , at 54.

195. Id.

196. For a more extended exposition of these concepts of confrontation and compulsory process, see Westen, supra note 185.

197. Tradition dictates that, as between the two sides, the prosecution goes first in presenting its case-im-chief. See note 198 infra. The confrontation clause mandates that the defendant be allowed to interrupt the prosecution's case-in-chief to present evidence in his defense by crossexamining prosecution witnesses immediately after the close of their direct testimony. See text accompanying notes $198-202$ infra.

198. It is often assumed that the prosecution's practice of presenting its evidence first is a matter not only of tradition, but of constitutional compulsion. See People v. Coleman, 13 Cal. 3d 867, 875-76, 533 P.2d 1024, 1032, 120 Cal. Rptr. 384, 392 (1975). I must confess, however, that I find it difficult to identify the source of this supposed requirement anywhere in the Constitution. There are two possible sources-the confrontation clause and the privilege against self-incrimination-yet neither provides a definitive answer. The confrontation clause is a rule of evidence that requires the prosecution to produce and tender for cross-examination the witnesses whose statements it imtroduces as part of its case against the defendant. In itself, however, the clause says nothing about whether the prosecution must present its case before or after the defendant puts on his case. Thus, as far as the confrontation clause is concerned, there appears to be nothing wrong with requiring the defendant to put on his case first, provided that once the prosecution puts on its 


\section{rupt the prosecution's case-in-chief by intervening to elicit evidence in}

case, it does so by presenting its evidence in its best available form. See generally Westen, supra note 185 , at $569-86,594-601$.

The more likely source is the privilege agamst self-incrimmation. Yet the Court has apparently rejected the proposition that a defendant may not be called upon to make any potentially incriminating disclosures until the prosecution first presents its case agamst him at trial. It will be recalled that the dissenters in Williams $v$. Florida challenged the notice-of-alibi statute on the ground that it required defendants to disclose potentially incriminating evidence before the government had presented its case-in-chief against him:

The defendant, under our Constitution, need not do anything at all to defend himself, and certainly he cannot be required to help convict himself. Rather he has an absolute, imqualified right to compel the state to investigate its own case, find its own witnesses, prove its own facts, and convince the jury through its own resources. Throughout the process the defendant has a fundainental right to reinain silent, in effect challenging the state at every point to: "Prove it."

399 U.S. at 112 (Black, J., concurring and dissenting). The inajority in Williams implicitly rejected this formulation of the privilege, and held instead that as long as a defendant has substantial pretrial discovery of the prosecution's case, he can be compelled to show his hand in advance of the state's presentation of its case-m-chief. It should follow that as long as a defendant has substantial pretrial discovery of the prosecution's case, he can also be required to put his case into evidence in advance of the state's case-in-chief, since doing so is no inore incriminating than disclosing his case. This conclusion finds support in the fact that with respect to the trial of minor offenses, many jurisdictions do require the defendant to present his evidence first. See PresIDENT's COMMISSION ON LAW ENFORCEMENT AND ADMINISTRATION OF JUSTICE, TASKFORCE REPORT: THE CoURTS 124 (1967); Note, Metropolitan Criminal Courts of First Instance, 70 HARv. L. REV. 320, 331 (1956).

To be sure, some commentators have argued that Williams can be construed more narrowly, and that Williams, so construed, is consistent with the traditional notion that a defendant cannot be compelled to make incriminating disclosures (or put his own case into evidence) until the prosecution first presents its case-in-chief against him. The arguinent is based on the premise that notice of an alibi is the kind of information that is generally useful to the prosecution only after the defendant begins to put his case into evidence and that such information cannot generally be exploited by the prosecution in the course of presenting its own case-im-chief. Accordingly, so the argument goes, since Williams required the defendant to disclose only abibi information, and since alibi information cannot easily be used by the prosecution as part of its case-in-chief, Williams does not stand for the proposition that a defendant can be required to make pretrial disclosures generally - or put his own case into evidence-before first hearing the state's case-in-chief against him. Alschuler, supra note 66, at 118 n.201; Nakell, supra note 37, at 497-502.

There are several problems with this narrow view of Williams. For one thing, it goes beyond what even the dissenters took the majority in Williams to mean. Thus, Justice Black (who presumably wished to construe the Court's opinion as narrowly as possible) concluded that the majority in Williams was prepared to require a defendant to inake "complete disclosure . . . of all evidence, testimony, and tactics he plans to use at . . trial," 399 U.S. at 114, without regard to whether the state might exploit the information in its case-in-chief. Furthermore, the lower courts have rejected this narrow view of Williams. Thus, soine have held that Williams extends to all defensive evidence, without regard to whether it is uscd by the state in its case-in-chief. See, e.g., Keller v. Criminal Court, 262 Ind. 420,317 N.E.2d 433 (1974). Still others, having adopted the narrow view of Williams as a guide for interpreting their own state constitutions, have nonetheless concluded that Williams "is not wholly consistent with our interpretation of the privilege against self-mcrimination." Allen v. Superior Court, 18 Cal. 3d 520, 524, 557 P.2d 65, 66, 134 Cal. Rptr. 774,775 (1976). Finally, this narrow view cannot easily be squared with the facts in Williams, because a notice of an alibi is the kind of disclosure that is capable of being used by the prosecution in its case-in-chief. See Allen v. Superior Court, 18 Cal. 3d at 526 n.4, 557 P.2d at 68 n.4, 134 Cal. Rptr. at 777 n.4; Scott v. State, 519 P.2d 774 (Alas. 1974); Kessell, supra note 66, at 891 n. 147, Nakell, supra note 37, at 500-02. And even if the disclosure does not lead to any particular item of evidence $\mathrm{m}$ the state's case-in-chief, the notice-of-alibi may still "incriminate" the defendant by 
his defense by means of cross-examination. To be sure, a defendant is not constitutionally empowered to call witnesses of his own choosing im the midst of the state's case-in-chief; he must wait until the close of the state's case to call his own witnesses. ${ }^{199}$ But he is constitutionally entitled to alter the gross order-of-proof by insisting that he be allowed to elicit evidence in his defense from prosecution witnesses by cross-examining them immediately upon the close of their direct testimony. ${ }^{200}$ Indeed, the right of a defendant to interrupt the state's presentation of evidence by cross-examining prosecution witnesses is at the core of the sixth amendment right of confrontation.

To illustrate this point, assume for a moment that the right of confrontation were repealed altogether. In that event, the state would not be required to produce as part of its case-in-chief the witnesses whose statements it introduces into evidence "against him"; nor would the state be required to allow the defendant to cross-examine such witnesses about the substance of their direct testimony agamst him. But that does not mean that the defendant would be left entirely unprotected. On the contrary, as part of his own case-in-chief, the defendant could still invoke his correlative right of compulsory process to produce and examine those very same witnesses for precisely the same evidence he would liave elicited from them on cross-examination. ${ }^{201}$ In that sense, the compulsory process clause already provides the defendant witl every benefit he would otherwise enjoy under the confrontation clause, with one important exception-more effective timing and sequence. The main (and perhaps the only) thing the confrontation clause adds to the compulsory process clause is that it gives a defendant the riglit to examine certain witnesses-i.e., those persons whose incriminating statements the prosecution introduces agamst the defendant in its case-in-chief - at the time during trial when the statements are first made to the jury and are uppermost im the jurors' minds. In other words, the essential attribute of the right of confrontation is that it regulates the defendant's order-of-proof: where the defendant would otherwise liave to wait to elicit impeaching evidence as part of his own case-in-chief, the confrontation clause allows him to interrupt the state's case-in-chief to elicit that evidence at a time when the impeachment will be most effective. ${ }^{202}$

helping the prosecution to narrow and otherwise plan its case-in-chief. See Kessell, supra note 66, at 884-89.

199. See Truman v. Wainwright, 514 F.2d 150, 152 (5th Cir. 1975).

200. See State v. Fisher, 222 Kan. 76, 79-82, 563 P.2d 1012, 1016-18 (1977) (the right of confrontation means the right to cross-examine the declarant contemporaneously with the admission of the declarant's hearsay statements, and the right is violated if the defendant has to postpone his examination of the declarant until he is ready to put on his own case-in-chief).

201. See Westen, supra note 198, at 613-24.

202. See Note, The Supreme Court 1970 Term, 85 HARv. L. REv. 195 (1971) (once the prose- 
This same point can also be illustrated by assummg that a state alters this traditional order-of-proof. Suppose, for example, that a state provides by statute that while a defendant has a right to cross-examine witnesses whose imcriminating statements are introduced against him, he must delay his cross-examination until after the close of the state's case. In that event, he would still have every opportunity he now has under the right of confrontation, except that he would have to postpone his examination of these "witnesses against him" until he was ready to proceed with his own case-m-chief. Yet that single difference in timing is the very thing that distinguishes the right of confrontation from the right of compulsory process. As far as the production and exainination of witnesses is concerned, he already has a right under the compulsory process clause to examine directly those very same witnesses in precisely the same way as he would on cross-examination. Consequently, if this hypothetical statute is unconstitutional, it is because it violates the defendant's right to examine the prosecution's witnesses at the poimt during the presentation of the state's case when their imcriminating testunony is freshest im the jurors' minds and hence when the defendant's examination would be most effective.

This point brings us back to Brooks, because Brooks provides constitutional underpinning for the second half of a defendant's interests regarding order-of-proof: just as the confrontation clause constitutionalizes the defendant's right to control certain aspects of the "gross" order-of-proof at trial, Brooks constitutionalizes the defendant's right to control the "internal" order-of-proof within his own case-in-chief. Brooks stands for the proposition that a defendant has a constitutional interest in being able to regulate the timing and sequence of evidence in his defense, and that the state may not abridge that interest in the naine of asserted objectives that could as easily be accomphished by less restrictive means. Moreover, the rationales that underlie the right of confrontation and the decision in Brooks are ultimately the sanie. Both rest on the assumption that the order-of-proof has an important effect on the outcome of criminal cases, and that the right of a defendant to present a defense through witnesses includes the right to present their testimony in an order that will render it effective.

One final task remams- to identify the textual source of the constitutional right implicit im Brooks. There are two possibilities: the due process clause of the fifth and fourteenth amendments and the compulsory process clause of the sixth amendment. Ironically, this turns out to be a subject on which cominentators have surprisingly strong feelings. Some commentators take the position that the explicit

cution has introduced incriminating hearsay stateinents against the defendant, it is more "effective" from the defendant's point of view to interrupt the state's case-in-chief and cross-examine the declarant immediately than to wait and examine the declarant as a witness for the defense). 
protections of the sixth amendment ought to be read narrowly, and that when one is in doubt as to whether a desired procedure is covered by one of these explicit provisions, one ought to presume that it is not and ought to attribute the procedure, instead, to the catchall of the due process clause. $^{203}$ Others, includimg myself, beheve to the contrary that it is the due process clause that ought to be read narrowly, and that one ought not to resort to the uncertain generalities of the due process clause unless one is convinced not only that a particular procedure is indispensable to a fair trial but that it cannot be brought within any of the several exphicit purposes of the sixth amendment. ${ }^{204}$ Consequently, since the purpose of allowing a defendant to control the internal orderof-proof is to enhance the effectiveness of witnesses in his defense, and simce the compulsory process clause is explicitly designed to enable a defendant to call "witnesses in his favor," I would attribute the constitutional rule of Brooks to what Louisell called the "organizing principle"20s of coinpulsory process-the right of a defendant to present a defense through witnesses in his favor. ${ }^{206}$

203. See, e.g., Clinton, supra note 126 , at $793-95,857-58$.

204. Westen, supra note 80, at 126-31. See Commonwealth v. O'Neill, 367 Mass. 440, 327 N.E.2d 662, 669 (1975) (Wilkins, J., concurring) ("I believe . . . that the case should be considered first under tlie . . . constitutional provisions dealing directly with the subject . . . before resort is had to the less specific due process provisions .....").

205. Letter of April/May, 1975, from David Louisell to Peter Westen.

206. The question of where in the Bill of Rights to locate a procedural guarantee also arises in connection with the right of a defendant to testify on his own behalf. The right to testify can be located, alternatively, cither in the due process clause of the fifth amendment or the compulsory process clause of the sixth amendment. Again, however, simce the coinpulsory process clause is specifically directed to the rights of the accused, and simce it is explicitly designed to guarantee a defendant the right to produce "witnesses in his favor," it is the natural locus of the right of a defendant to call himself as a witness for the defense. In that respect, the right of compulsory process can be regarded as the right of a defendant to call any witness, including himself, who possesses evidence in his favor. See Westen, supra note 80, at 120. See also Wright v. Estelle, 572 F.2d 1071, 1076 (5th Cir. 1978) (Godbold, J., dissenting) (the right of a defendant to testify in his own defense "may be considered as included in the Sixth Amendment's guarantees of the defendant's right ... to present witnesses on his behalf (in the instant case, to present himself as a witness") (emphasis added)). 
